\title{
Festes a santa Eulàlia a la Barcelona barroca (1686): relacions escrites i obres d'art; escenes martirials i el perfil de la ciutat
}

\author{
Cristina Fontcuberta i Famadas \\ Departament d'Història de l'Art - Universitat de Barcelona ${ }^{1}$ \\ cristinafontcuberta@ub.edu \\ http://orcid.org/0000-0002-3033-6061
}

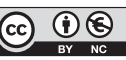

Rebut: juny de 2018.

Acceptat: octubre de 2018.

\section{Resum}

El 1686 es van celebrar grans festes a Barcelona en honor a santa Eulàlia per commemorar l'extensió del res de la patrona decretat pel papa Innocenci XI. A partir de la relació, de llenguatge retòric, que descriu la processó que va recórrer la ciutat encapçalada pels consellers i en què participaren els diferents ordes religiosos, aquí es proposa una reconstrucció d'aquelles obres d'art que s'hi exhibiren. Si bé la majoria d'obres eren efímeres, altres es poden identificar amb peces que han perviscut, de manera que totes elles amplien el nostre coneixement del passat artístic. A més de remarcar-ne les característiques properes a l'estètica barroca en voga, l'interès d'aquestes obres rau en la representació del martiri de la santa i la presència del relleu de la ciutat de Barcelona al fons. Aquestes característiques s'inscriuen alhora en una promoció contrareformista dels sants locals.

Paraules clau: santa Eulàlia; barroc; literatura artística; relació de festes; Barcelona; Contrareforma; escultura; martiri; perfil urbà

Resumen. Fiestas a santa Eulalia en la Barcelona barroca (1686): relaciones escritas y obras de arte; escenas martiriales y el perfil de la ciudad

En 1686 se celebraron grandes fiestas en Barcelona en honor a santa Eulalia para conmemorar la extensión del rezo de la patrona decretado por el papa Inocencio XI. A partir de la relación, de lenguaje retórico, que describe la procesión que recorrió la ciudad encabezada por los consellers y en que participaron las diferentes órdenes religiosas, aquí se propone una reconstrucción de las obras de arte que se exhibieron en ella. Aunque la mayoría de obras eran efímeras, otras pueden ser identificadas con piezas que han pervivido, de manera que todas ellas amplían nuestro conocimiento del pasado artístico. Además de remarcar las características cercanas a la estética barroca en boga, el interés de estas obras reside en la representación del martirio de la santa y la presencia del relieve de la ciudad de Barcelona al fondo. Estas características se inscriben a su vez en una promoción contrarreformista de los santos locales.

1. Aquest estudi s'emmarca en el projecte «Justicia y juicio: representaciones artísticas en la Cataluña medieval y moderna. Emplazamientos, programas iconográficos, contextos y modelos», finançat pel Ministeri d'Economia i Competitivitat i dirigit per la Dra. Rosa Alcoy i la Dra. Cristina Fontcuberta (HAR2017-85910-P). 
Palabras clave: santa Eulalia; barroco; literatura artística; relación de fiestas; Barcelona; Contrarreforma; escultura; martirio; perfil urbano

\begin{abstract}
Feasts to Santa Eulalia in baroque Barcelona (1686): written accounts and works of art; martyrdom scenes and the city skyline
\end{abstract}

In 1686, lavish celebrations were held in Barcelona in honour of Santa Eulàlia to commemorate the extension of the praying of the patron decreed by Pope Innocent XI. Starting from the rethorical «relació», which describes the procession that crossed the city headed by the councillors and in which the different religious orders participated, here we propose a reconstruction of those works of art that were exhibited during the festivities. Although most of the works were ephemeral, others can be identified with pieces that have survived, thus contributing to a better knowledge of the artistic past. In addition to highlighting the characteristics of the Baroque style in vogue, the interest of these works lies in the representation of the martyrdom of the saint and the presence of the relief of the city of Barcelona on its background. These characteristics are part of a Counter-reformist promotion of local saints.

Key words: Saint Eulàlia; baroque; artistic literature; festivities accounts; Barcelona; CounterReformation; sculpture; martyrdom; city skyline

El 31 d'agost de 1686 el papa Innocenci XI va decretar l'extensió del res universal de santa Eulàlia, que havia estat demanat pel Consell de Cent des de març de 1685. Aquesta extensió implicava una major consideració de la patrona en la jerarquia dels sants, i per això, quan es va conèixer el decret el 4 d'octubre, es van convocar grans festes a la ciutat, les més importants segons Narcís Feliu de la Penya (Feliu, 1709). Si bé tant al dietari del Consell de Cent com als dietaris de la Generalitat s'hi registrà aquesta informació (Manual, XX: 259-264; Sans i Travé, 2014: 793, 843), ${ }^{2}$ gràcies a un conjunt de textos redactats i editats el mateix 1686 en podem conèixer molts més detalls (Festivos, 1686). ${ }^{3}$

En època moderna, quan les oligarquies ciutadanes, en connivència amb les elits eclesiàstiques, van afavorir determinats cultes que ajudaven entre altres coses a la creació d'una identitat col-lectiva, santa Eulàlia esdevingué una de les santes protagonistes de la «corografia» barcelonina. ${ }^{4}$ Tal com han analitzat alguns estudis, el seu culte s'anà creant amb diversos textos historiogràfics de marcat caràcter panegíric en els quals es lloaven les excel-lències religioses de la ciutat en una promo-

2. Al dietari es registren els esdeveniments en relació amb l'extensió del res de la santa des que se'n coneix el decret el 4 d'octubre de 1686 fins a la celebració de la processó el dia 30 i la pregària a Santa Maria del Mar el dia 31. El decret en llatí s'hi afegeix com a apèndix, així com els veredictes que anunciaven els guanyadors del concurs de poesia i els del concurs d'ornaments, celebrats en honor a la santa, p. 503, 505, 507.

3. Biblioteca de Catalunya, Fullets Bonsoms (en endavant F. Bon.) 232. A la primera pàgina s'esmenta el llarg camí de la petició del res universal per part del Consell de Cent des de 1685, passant pel bisbe i el capítol, els reis i el papa.

4. Per a una síntesi de la imatge de la santa en època moderna, Fontcuberta, 2018. 
ció dels sants locals, una propaganda en gran part empesa pel Consell de Cent (Torres, 2014; Betrán Moya, 2010; Valsalobre, 2012). Així, al text de 1686 se cita la Coronica universal del Principat de Catalunya (1609) de l'historiador Jeroni Pujades com una de les fonts per a la vida de santa Eulàlia, afirmant que es tractava de la Protomàrtir d'Espanya (Festivos: 36).

Les relacions de festes i descripcions esdevenen fonamentals per a la història de l'art, per tal com van deixar constància d'alguns episodis del passat artístic que d'altra manera no hauríem conegut. Des que autors vuitcentistes com Jakob Burckhardt assenyalaren la importància de la festa en la societat del Renaixement, ha estat un àmbit àmpliament estudiat (Burckhardt, 1860) i se n'ha anat reivindicant la importància i explorant llur riquesa en èpoques posteriors i territoris diferents (Jacquot, 1960; Strong, 1984; Fagiolo i Carandini, 1977-1978; Fagiolo, 1997; Bonet Correa, 1990, entre d'altres). Les festes romanes, entre les quals també s'inclouen les celebrades amb motiu de canonitzacions i processons, van generar una gran quantitat de documentació escrita i iconogràfica. Analitzats en el seu conjunt, aquests documents condueixen a la conclusió que la festa efímera esdevingué la «forma simbòlica» del barroc, en què la imatge era la protagonista i en què la finalitat d'aquesta «meraviglia» s'aconseguia amb la persuasió i la propaganda (Fagiolo i Carandini, 1977-1978: VII). La dificultat i alhora la necessitat d'estudiar les obres efímeres que sovint s'hi exhibien ha estat posada en relleu per diversos historiadors de l'art, i cal recordar que la naturalesa poc perdurable i poc valuosa dels mateixos materials amb què estaven fetes, les condemnava freqüentment a la desaparició o al reciclatge.

Els especialistes han analitzat part de l'abundant i rica documentació que van generar les festes d'època moderna, i n'han destacat la gran producció de gravats $\mathrm{i}$ imatges que eren comissionats pels mateixos promotors de les festes per tal de preservar en la memòria tanta pompa i magnificència, contribuint així a enriquir i a engrandir el «Gran teatre del món» que fou Roma al llarg del segle XVII (Tozzi, 2002: 166). Si Roma era el centre del poder i de les festes eclesiàstiques, molts altres territoris i ciutats van dedicar festivitats als sants, que cal estudiar tenint en compte una pluralitat de mirades i de coneixements (Dompnier, 2009). En territoris de la monarquia hispànica, i en plena lluita per l'ortodòxia catòlica, moltes ciutats celebraren la promoció, la beatificació, la canonització o el patronatge dels propis sants patrons. Les festes en honor seu, celebrades a partir d'uns mecanismes establerts a inicis del segle XVII amb diverses característiques comunes i altres particularitats, han estat analitzades per una bibliografia creixent, impossible d'enumerar aquí (entre d'altres, Pedraza, 1982; Río Barredo, 2000; Campos, 2002; García Bernal, 2006 i 2013; Mínguez i González, 2011; Vincent-Cassy, 2010). ${ }^{5}$ D'entre les múltiples festivitats, a la segona meitat de segle destaquen les que es van celebrar a Sevilla per a la canonització de sant Ferran el 1671, en què

5. S'ha anomenat el Segle dels sants espanyols, i, entre d'altres, se celebraren les festes de canonització de sant Ramon de Penyafort el 1601, les de la beatificació de Lluís Beltrán el 1608 i de sant Isidre el 1620, i les de la canonització de santa Teresa d'Àvila, Ignasi de Loiola, Francesc Xavier i Felip Neri el 1622, i la de sant Pere Nolasc el 1629. 
la brillantor literària, emblemàtica i artística arribà al seu zenit i la Relació escrita per Fernando de la Torre Farfán inclogué riques làmines il-lustrades per artistes de qualitat que permeten conèixer les màquines i l'aparell arquitectònic instal-lats a la catedral sevillana (Bonet Correa, 1990: 36-37).

Que Barcelona era una ciutat festiva, tenint en compte aquest context més ampli, queda reflectit precisament en la quantitat de relacions que descriuen celebracions dutes a terme per motius ben diversos, tant seglars com religiosos. Si bé algunes festes eren esperades i se celebraven de manera regular, altres esdevenien ocasions úniques, com les festes que commemoraven la promoció per part del Vaticà d'un culte nou o renovat, tal com s'esdevingué amb la translació de les relíquies de sant Cugat el 1628 o la beatificació de sant Joan de la Creu el 1675, el mateix any de la canonització de sant Oleguer, o les festes de 1686 que aquí ens ocupen. Malauradament, en el cas català aquestes relacions de festes rarament s'acompanyaren d'obres gràfiques, ${ }^{6}$ i més habitualment no n'han quedat imatges, com és el nostre cas, en què només acompanya la lletra un gravat amb l'escut de la ciutat a la portada. Els motius d'aquesta mancança, que aquí només podem esmentar, cal trobar-los en la mateixa tradició gràfica catalana, amb uns recursos molt més minsos, un tarannà poc original i innovador, $\mathrm{i}$ segurament també en una cultura visual, la del món hispànic, molt menys privilegiada que la de l'escriptura (Boiteux, 1985: 129).

Malgrat aquesta absència iconogràfica, en les relacions catalanes es descriuen obres d'art, i se'n pot extraure informació valuosa que permet traçar algunes pistes tant d'imatges concretes, perdudes o pervingudes, com del relat evocador de l'atmosfera en què s'exhibiren. Els estudis sobre el barroc i les relacions escrites d'aquella època en àmbit català també han anat augmentant els darrers anys, i les visions més àmplies han servit de marc a articles especialitzats. Algunes d'aquestes anàlisis provenen tant dels estudis literaris com de la història $i$ de la història de l'art (Ainaud, 1989; Triadó, 1999; Ettinghausen, 2010; Garganté, 2011; Torres i Expósito, 2015). Tenint en compte aquests estudis, en el text present es pretén indagar, a partir de la descripció de les festes de 1686, algunes característiques del context artístic i les obres exhibides i es vol posar en relleu les confluències artístiques de la festa dedicada al culte de la patrona de Barcelona, la qual s'inscriu plenament en la cultura barroca de les acaballes del segle XVII, segons ha estat definida per autors com Maravall, que la considerava una cultura dirigida i programàtica, massiva, que movia a través dels afectes amb mitjans com la festa $\mathrm{i}$ l'art (Maravall, 1990: 438).

La relació de festes de 1686 titulada Festivos y magestuosos cultos és un document de quasi cent quaranta pàgines que descriu les diverses celebracions dedicades a la santa amb motiu de l'extensió universal del seu res. L'autoria

6. Una excepció fou el gravat de Francesc Via per a la descripció de la festa dels argenters amb motiu del nomenament de Joan Josep d'Àustria com a ministre de Carles II el 1677 (Garcia Espuche, 2010: 139-195). Una altra és el dibuix atribuït a Guillem Reig de la processó de Diumenge de Rams de la Venerable i Il-lustre Arxiconfraria de la Verge dels Dolors del convent del Bonsuccés de Barcelona (Miralpeix, 2017). 
d'aquesta tipologia d'obres, escrites com a encàrrec dels promotors de la festa, sovint és desconeguda i habitualment es van redactar en castellà. L'ús del castellà fou majoritari en les relacions editades a Barcelona, exceptuant les dels anys de la Guerra dels Segadors. A més de representar una opció estètica més, es responia així a les expectatives d'un mercat més ampli (Ettinghausen, 2010: 201). ${ }^{7}$ En el cas que ens ocupa, es tracta d'un recull de diversos textos, incloent fragments pertanyents a autors diferents, com l'explicació inicial del notari i escrivà major de la ciutat Pere Trelles sobre la consecució de l'extensió del res per a santa Eulàlia, o els villancets i cobles en honor a la santa titulats «Anuncia Barcelona felicidades a España» (Festivos: 20-26; 56-64). Com que es valorava la teatralitat, en aquestes ocasions era habitual que es convidés a dir sermons a predicadors experimentats per tal de fer-ho lluir més, com el cas de l'oració panegírica La capitana en campaña de Ramon Costa (1640-1703), teòleg i predicador. La part més interessant per al nostre propòsit és la que descriu la processó i les obres efímeres que s'hi exhibiren. Lluny d'oblidar-ne la presència, la història de l'art en reivindica el coneixement per tal de completar la nostra visió del passat artístic i de l'ús de l'espai públic. Amb tot, el fet que majoritàriament aquestes obres no fossin considerades grans encàrrecs pels artistes, fa que es compliqui llur atribució i la mateixa supervivència de la peça. Però afortunadament hi ha excepcions i es coneix, per exemple, l'autoria d'algunes creus processionals de tallers catalans, malgrat que es consideressin un gènere menor a Catalunya. ${ }^{8}$

Després d'aquesta descripció, segueix una Peroración a la santa i finalment es narra el concurs de poesies i jeroglífics que es feu en honor seu, seguint una tradició de certàmens que tingué especial vitalitat a partir de 1580. Malgrat que alguns grans literats com Lope de Vega o Calderón de la Barca participessin en concursos semblants d'altres territoris hispànics (Vincent-Cassy, 2010), la qualitat literària era relativa, i del cas català Rossich destaca sobretot llur funció social i la promoció del plurilingüisme (Rossich, 2003). Tal com es feia en altres certàmens, es convocaren tres premis en tres llengües (llatí, català i castellà) que guanyaren respectivament el capità Belisario, el Dr. Ferran Prevere i Francisco de las Torres. El premi de pintura s'atorgà al jeroglífic de Francesc Amat i de Planella, comte de Castellar i militar que participarà a la Guerra dels Nou Anys amb la coronela. Es diu que el seu poema en octava estava sota una excel-lent pintura de santa Eulàlia, a manera de jeroglífic, «(...) en que sobrepuso el pinzel a la pluma, y por èl llevo el Premio de mejor Pintura» (Festivos: 139). Si de la pintura no s'explica res més, aquests poemes, que tal vegada els filòlegs analitzaran en treballs futurs, estan inclosos en les darreres pàgines de la relació, i es van fer tant

7. En les festes de canonització de sant Ramon de Penyafort el 1601, fou Jaume Rebullosa, el prior del convent de Sant Francesc de Balaguer, l'encarregat d'escriure un text de cinc-centes pàgines (Ettinghausen, 2001).

8. S'han conservat alguns monuments de Setmana Santa i la famosa escultura del Llit de la Verge de Lluís Bonifaç a la catedral de Girona i, en el dibuix de Guillem Reig de la processó de Setmana Santa conservat al Museu d'Història de Barcelona, s'hi representen alguns passos processionals realitzats per artesans reputats d'aleshores, que tampoc han perdurat. (Mata i París, 2006; Triadó, 2016: 399-483; Mercader, 2015; Miralpeix, 2017: 9). 
per concórrer al premi, «(...) como á la devoción de la Santa» (Festivos: 125). Entre els membres del jurat que havien de valorar el concurs de jeroglífics hi havia Magí Cases, catedràtic de retòrica de la Universitat de Barcelona, que ja havia participat en altres concursos, i que ens interessa com a promotor d'obres artístiques. Entre d'altres, havia encarregat a Joan Jolis els quatre gravats per a la seva obra Desenganys del Apocalipsis, que il-lustraven els Novíssims, una qüestió d'interès en el repertori barroc a finals del segle XVII (Socias, 1993).

Tant la mateixa celebració com la relació anònima que l'explicava s'adequaven a les característiques habituals d'aquestes festes i llurs descripcions, de les quals s'ha remarcat la poca tendència al canvi al llarg dels segles XVII i XVIII. Les festes foren encapçalades pel Consell de Cent, i, a més de presidir les misses i els tedèums a la catedral, les autoritats tancaren la processó en què, a banda dels altars i de les creus exhibides per les diverses comunitats religioses i pels gremis, també es promogué la decoració de frontispicis de cases particulars. S'explicita en la relació que la processó farà el mateix recorregut i tindrà la mateixa forma que la del Corpus, que era la festa emblemàtica de l'època del barroc, i, essent el model d'altres processons semblants, s'hi reflectia l'ordre social, amb la desfilada de tots els seus agents que esdevenien alhora una metàfora de la ciutat en què els ciutadans dels diferents barris rivalitzaven per acollir aquests «enginys» de l'arquitectura efímera (García Espuche, 2010: 83-89).

Malgrat que tota la ciutat s'hi sentís involucrada, tal com s'especifica al dietari, eren les autoritats que pagaven aquests actes, i, a més, s'havien preocupat de fer ben visibles les celebracions a través de cartells que les anunciaven i que van fer enganxar per la ciutat. ${ }^{9}$ Per això, cal igualment considerar les descripcions de les festes com a eines propagandístiques, de legitimació del poder d'aquestes autoritats, $i$, en consequiència, els esdeveniments s'hi relaten amb una dosi d'exageració important a partir d'un llenguatge retòric i hiperbòlic, tal com també s'havia fet al món italià i hispànic (Díez, 1986; Rodríguez de la Flor, 1999). En efecte, al text català, quan es parla del fervor de la ciutat envers la santa, s'afirma que «(...) ningún obsequio basta, ninguna demostración sobra» i sobre la processó s'assegura que «(...) no hay ceremonia en muchos años que se hubiese visto tal» (Festivos: 48, 113). El segle XVII ha estat considerat el període d'or de la crònica de celebracions i la seva característica retòrica cal entendre-la com un dels mitjans per a fer publicitat i rendibilitzar els diners que havien costat les festes (Ettinghausen, 2010: 43; Redondo, 2002).

Certament, la ciutat estava involucrada en un espectacle total que implicava una confluència de les diverses arts, i en què s'interpel-lava als sentits a través de l'ornament i l'artifici que alhora esdevenien «(...) un mitjà de transformació de la realitat que sempre era menys agradable» (Garganté, 2011: 68). Al llarg de tota la relació es fan nombroses referències a un element molt característic de la cultura barroca, l'evocació i la importància dels sentits. Ens podem imaginar com a tra-

9. L'anunci del 14 d'octubre es tornà a fer amb "sedulons" estampats i enganxats arreu de la ciutat el 29 d'octubre (Manual: 260 i 262). A la relació s'hi inclou un exemplar (Festivos: 12-17, i es conserva a la Biblioteca de Catalunya, F. Bon. 6563). 
vés de totes les decoracions, tant a l'interior de la catedral com als carrers, la vista dels espectadors quedava sacsejada per formes i colors. Així, la façana de la catedral es va decorar amb tres ordres dels tapissos més preciosos, «para que sobresaliera ahora con alguna singularidad nunca vista» (Festivos: 18).

La llum i els aspectes lumínics es consideraven de gran importància en aquestes festes, i els cronistes de l'època subratllaven l'entusiasme per la ciutat encesa i lloaven les transformacions nocturnes com a gesta també col·lectiva. Com en moltes d'aquestes celebracions, es van encendre lluminàries, i entre la decoració de la catedral hi havia «(...) diversidad de Arañas, con cuyas luces todo el cuerpo de la Iglesia se gozava, con indicible hermosura» (Festivos: 18). Quan es recorda el trasllat de les relíquies de la santa esdevingut el 1339, s'afirma que en dos dies es van cremar fins a vuit-cents ciris a la seu en honor a la santa, dels quals ens en podem imaginar tant la llum com l'olor que desprenien. A més, la llum física apareix com a metàfora de llum espiritual, i la llum del Sol competeix amb la llum d'Eulàlia, mentre que Ramon Costa, prior del convent de Santa Caterina, en el segon sermó de la relació celebra la difusió de la llum d'Eulàlia als altres regnes (Festivos: 56 i 82). ${ }^{10}$ A més de la llum, els colors també eren molt aplaudits, i de fet el premi de pintura es donaria al «(..) pintor que hiziere, amás de lo significativo, un Geroglifico de mas bella traça y fantasia, y de mas vivos y delicados colores» (Festivos: 17). D'aquesta manera, en la descripció de les creus de les comunitats sorprèn la dels carmelites, «(...) salpicada de mariposas azules, retocadas con primorosos y verdes matizes» (Festivos: 114). El color també s'interpretava de manera simbòlica, i semblen abundar els blaus i els daurats, però el blanc hi apareix com a símbol de la puresa i la caritat, i el verd és el de l'esperança (Festivos: 18 i 102; 56).

També l'oïda dels assistents als actes quedava interpel-lada a través de sons i música. Així, el repic de les campanes, o l'«estruendo» de l'artilleria acompanyen la resolució del 4 d'octubre de celebrar aquestes festes. Abans del primer intent de dur a terme la processó el 23 d'octubre, de la suspensió a causa de la pluja i de la seva celebració definitiva el dia 31, es va celebrar la «passada de la professó general», que consistia en l'exhibició i enaltiment de la bandera de santa Eulàlia al so de les trompetes i timbales i amb l'acompanyament dels cavalls cotoners, els diablots, el drac, la brívia, el gegant i la gegantessa (Manual, XX: 260-262). A més, quan es van fer les Vespres i Maytines a la catedral, foren «(...) a cinco Coros, con tal magestad de Musica, que parecio averse la armoniosa consonancia del Cielo, baxado a aquel Sacro Templo de la Cruz» (Festivos: 19). També cal recordar que es van escriure i cantar cobles i villancets per a l'ocasió, dels quals es coneix la música escrita en un manuscrit a la Biblioteca de Catalunya. ${ }^{11}$ A la música segueix l'oratòria del sermó d'A. Riu, que en descriure el tedè-

10. «Luzía antes Eulalia solo sobre la casa material, politica, y civil de la Ciudad de Barcelona y sobre la mística, y espiritual de su Cathedral, y Obispado, como ojeto de sus divinos cultos, determinada era su luz, y particulares sus influxos, luz parecía aerea; pero ahora celestuales se ostentan sus dorados rayos, pues se estienden, y dilatan universalmente por toda España para que vea como en ella, y por ella ha de alabar a Dios en los solemnes aplausos de su Rezo».

11. Biblioteca de Catalunya, M 743/1. 
um afirma: «Entonces se oyeron las voces de la alabanza: Te Deum Laudamus, oy se escuchan los ecos de aquellas voces», o bé descriu un «(...) profundo y respetoso silencio que duró por espacio de media hora». Altres villancets que es cantaren i apareixen a la relació de manera anònima, es poden atribuir a Joan Barter, l'organista i mestre de capella de la catedral de Barcelona entre 1682 i 1696, gràcies a un document que es conserva a la Biblioteca de Catalunya (Villancicos, 1686). ${ }^{12}$

L'olfacte també intervenia en aquest espectacle total. A més de les olors que imaginem que desprenien les decoracions florals i de fruites col-locades en molts altars efímers de les comunitats, en la poesia guanyadora en castellà es diu que «(...) rezar de aquesta Santa / huele à Pasqua / y sabe à gloria». Però la descripció més interessant en aquest sentit és la de l'olor que va desprendre el sepulcre de la santa l'any 1339, en la translació de les relíquies, un cop els mestres de fàbrica de la seu l'havien sepultada i coberta amb el túmul i les escultures i que l'autor anònim de la relació descriu amb cura. Es tracta, evidentment, d'una olor de santedat, que movia a la devoció (Festivos: 54$).^{13}$

A més d'aquesta atmosfera festiva i sumptuosa, el text ens ofereix descripcions d'obres d'art. Així, la relació permet analitzar el vocabulari artístic que s'hi utilitzava amb certs conceptes que hi dominaven, i, a més, ofereix la possibilitat d'indagar sobre algunes obres d'art concretes. Així, quan es descriuen els altars de les diverses religions dedicats a la santa, s'esmenten les belles traces i els singulars ornaments, i la diversitat de la inventiva, i abunden les paraules artifici, o perspectiva, i la decoració de les capelles es va fer amb «aliño, compostura y curiosidad» (Festivos, 102: 12-20). Es lloa molt la «proporció», tant dels espais i les distàncies com de les escultures (Festivos, 104, 115, 105), i aquest terme tan important en la teoria de les arts des de molt temps enrere, es repeteix abusivament. També la imitació de les obres respecte de la realitat és una idea molt valorada en la relació. Així, la creu de sant Miquel tenia «(...) unes uvas y unos pampanos muy bien imitados», com també ho eren tant el pelicà de l'escultura de la santa Teresa dels carmelites com els xipresos que adornaven l'altar dels pares clergues regulars al carrer Montcada (Festivos, 114, 118, 107).

Entre la variada decoració dels diversos altars, creus i tabernacles apareix esmentada la presència de «Niños de Nápoles» o de «Niños y escaparates de

12. Biblioteca de Catalunya, F. Bon. 5547. La portada està decorada amb un escut xilogràfic de la ciutat de Barcelona. Barter, natural de Mequinensa, fou mestre de capella i organista a Lleida i, a partir de 1682, a la Catedral de Barcelona, fins al 1696, quan es jubilà i fou substituït per Francesc Valls. Entre la seva producció musical religiosa, a més de villancets, hi ha psalms i un magníficat.

13. «Y es mucho de notar que del dicho santisimo cuerpo, estando encima de los dichos Altares, y yendo, y bolviendo en la procesion, y estando en su sepulchro, salia y manava maravillosamente, y con un modo espantoso un olor suavissimo, maravilloso y espantoso, como de Cinamomo y de Balsamo, y de diversos Aromatas que olian bien, y henchia los dichos lugares. Y aun tambien estado ya la dicha Tumba llena y cubierta en la referida forma, hechava este olor que llegava y penetrava a todos los que alli estavan, con admiracion y espanto dellos». 
Nápoles» (Festivos, 105, 109 i 119). ${ }^{14}$ Amb aquests noms es feia referència a les escultures exemptes elaborades en tallers de Flandes, Itàlia i Espanya que mostraven una estesa devoció religiosa a l'època. El tema de la infància de Crist fou especialment cultivat d'ençà de la Contrareforma com a tema de meditació en un sentit ascètic i profund semblant als de la Passió, atès que la imatge infantil del Nen Jesús, sovint representat amb un gest de benedicció i majestuositat, alhora el mostrava com a futur salvador (Mâle, 1985: 281-289). ${ }^{15}$ Els «escaparates» segurament fan referència a les vitrines o urnes de cristall que habitualment contenien imatges religioses en cera, destinades a convents, gabinets o cambres de cases de famílies benestants. Al segle XVI els ceratoli florentins van destacar-hi, amb un important impuls de la ceroplàstia en la Itàlia renaixentista tant per a escultures anatòmiques com per a retrats. En la segona meitat del segle XVI es desenvoluparen obres de petites dimensions exemptes i definitives, no tan sols models, i a inicis del segle XVII es difongué a Espanya. De fet, a les col·leccions reials ja apareixen notícies de dos petits Nens el 1596, i personatges com Pompeo Leoni o Calderón de la Barca en posseïen (Estella, 1993: 149-160; Rivera, 1992; Henares, 2006). Sembla que alguns dels exemplars conservats del segle XVII podrien ser de manufactura hispànica i és que alguns escultors andalusos gaudiren de prestigi en l'art de la cera. Tant la devoció com les escultures s'escamparen en territoris espanyols i arribaren a convertir-se en una de les variants més difoses de la seva plàstica. Des dels models més primerencs de Martíñez Montañés el 1606 per a la catedral de Sevilla, de Juan de Mesa, passant posteriorment per Francisco Salzillo i arribant fins als cultivadors d'aquesta temàtica en el barroc tardà hispànic, «(...) la infància de Crist inundà esglésies, convents i oratoris privats tot indicant clarament les preferències devocionals d'una gran part de la societat espanyola» (Garriga i Martín González, 1996: 413). Sovint foren els convents de monges que apreciaren aquestes escultures i també altres clients les demanaren per als seus oratoris privats com el mestre de les fonts de la ciutat, Jacint Santacana, que el 1619 posseïa, a més de sis quadres, una capelleta de fusta amb sant Matxí de marbre i una figura de «bulto» del nen Jesús (Perelló, 1996: 53). A banda de la cera i la fusta, també n'hi havia de peltre policromat, marfil i terracota. Si aquestes obres de la processó catalana derivaven d'un model andalús o d'un model napolità, com el del taller d'Aniello i Michele Perrone que havia treballat per a la cort virregnal i havia inspirat Salzillo, no es coneix. Malauradament, el cronista anònim no proporciona cap més dada sobre els materials, l'estil o la tipologia de les peces esmentades. Les obres de Mena o Salzillo conservades en museus catalans, com els presents en la col·lecció del Marès (Garriga i Martín González, 1996: 309, 413, 438) o les escultures de Juan de Mesa (ca. 1615-1625) i de Lluís

14. Apareixen a la plaça de l'Àngel en l'altar dels pares trinitaris, al costat de Santa Maria del Mar en l'altar dels pares clergues menors de l'Esperit Sant, i en el tabernacle dels pares de sant Francesc de l'Observança i sant Domènec.

15. Algunes de les primeres representacions del Nen Jesús com a figura exempta, dempeus i nua aparegueren en els gravats alemanys de finals del segle Xv, que foren models per a les escultures de mestres flamencs i germànics, que al seu torn esdevingueren un model difós arreu d'Europa. 
Bonifàs (1750-1775) al Museu Nacional d'Art de Catalunya potser ens acostaran a prototipus propers als exemplars que s'exhibiren aleshores pels carrers de la ciutat. També podria ser que es tractés d'obres d'àmbit més popular, semblants a aquelles peces de vestir que aparegueren poc després, a la segona meitat del segle XVIII, en terres catalanes, anomenades «de cap i pota» (Cea, 1992). Si bé en aquest sentit caldrà romandre en el terreny de les conjectures, la relació de les festes a santa Eulàlia testimonia la devoció i la presència artística d'aquest culte en la Barcelona moderna.

A la processó de 1686 es passejaren també diverses escultures en cera de la santa, ornamentades amb algunes escenes fetes de materials com paper o cartró. Un bon nombre d'aquestes escultures eren exemptes i cal recordar la llarga tradició de l'ús d'exvots en cera, i l'arribada d'aquest art en l'ambient contrareformista hispànic al segle XVII, quan les qualitats del material s'adaptaven tan bé a la recerca de realisme i quan alguns artistes com Juan de Revenga l'arribaren a introduir a la cort. A més dels Nens ja esmentats, les parelles d'ànimes i els novíssims - motius que responen a les idees de reflexió sobre la mort divulgades per ordes com els jesuïtes - foren altres temes repetits en aquesta estatuària. Malgrat que en nombre i complexitat menor que a Itàlia, també s'han conservat en àmbit espanyol algunes escultures en cera dedicades a sants com santa Teresa de Jesús, una de les santes més venerades a l'època (Sigüenza, 2015).

En la relació de 1686 apareix el terme piràmide per a designar els altars i les obres que exhibiren els diferents ordes, com la de la confraria de Santa Eulàlia o la de Sant Agustí al Born, en què al cim de l'altar hi havia l'estàtua del sant, que, segons l'autor i fent un joc de paraules, «(...) siendo precepto en regla de Arquitectura que las Piramides rematen agudamente, terminase esta en San Agustín que fue la agudeza misma» (Festivos: 110, 108). Malauradament, tampoc no en tenim cap imatge com les que es conserven en l'àmbit italià. Si bé la forma piramidal o d'obelisc s'utilitzava en els monuments escultòrics des d'antic, fou difosa altre cop en l'art modern a partir sobretot del trasllat de l'obelisc egipci que Domenico Fontana dugué a terme el 1586 a Sant Pere del Vaticà per ordre del papa Sixt V i que, segons els especialistes, va ajudar a ordenar la ciutat i a desenvolupar plantejaments que anticiparen les idees urbanístiques del segle XVII (Norberg-Schulz, 1980: 12; Wittkower, 1979: 25-28; D’Onofrio, 1967). Més tard, l'obelisc realitzat per Bernini a la Piazza Navona per a commemorar l'any jubileu de 1650 sota el patrocini del papa Innocenci X va ser molt famós (Tozzi, 2002: 179). A Barcelona, en canvi, si bé s'esmenten piràmides en altres relacions de festes com la de sant Oleguer (Torres i Exposito, 2015: 42), l'art públic del segle XVII es reduïa a modestos obeliscs commemoratius o conjunts escultòrics com la Font del Vell, a l'actual Pla del Teatre, o la piràmide del Pedró, encarregada el mateix 1686 pel Consell de Cent com a part de la promoció del culte de la patrona. El cap de la santa esculpit per Lluís Bonifaç conservat avui al Museu d'Història de Barcelona és l'única part supervivent del monument encarregat el 1670 en record d'un dels martiris de la patrona que segons la llegenda tingué lloc en aquest punt de l'actual barri del Raval (Martinell, 1948: 67; Mata i París, 2006: 

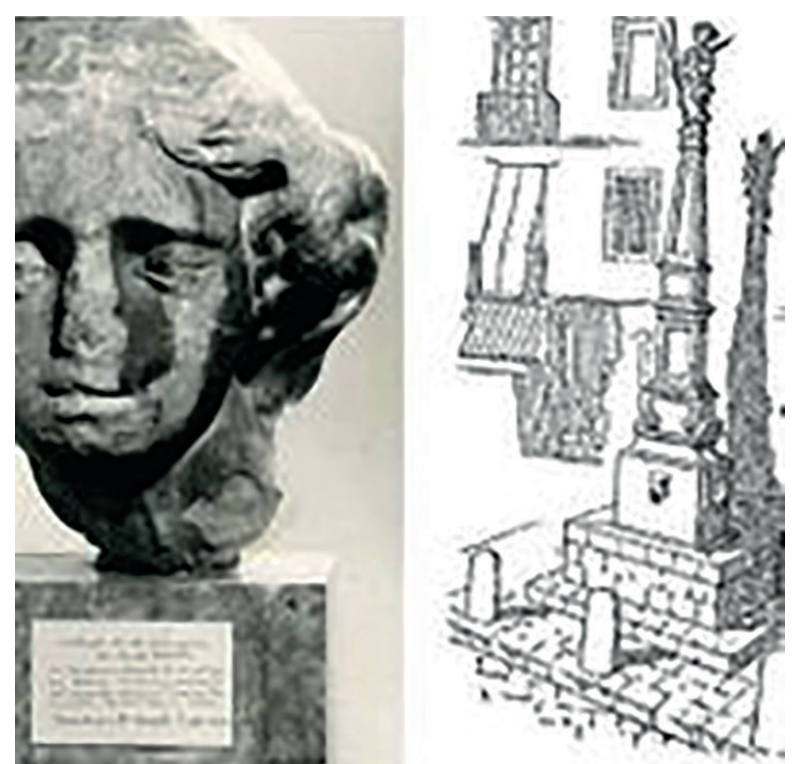

Imatge 1. Reproducció de la Piràmide del Pedró i cap de santa Eulàlia de Lluís Bonifaç, MUHBA, 1686.

32; Perelló, 1996: 338-348). ${ }^{16}$ Malgrat que han sobreviscut poques obres de la producció de Bonifaç, se'l considera un dels mestres que excel-liren en el coneixement de la plàstica de l'alt barroc i del repertori d'imatges sagrades que es difongueren des d'Itàlia amb la Reforma catòlica, caracteritzades per la recerca de fórmules persuasives, de figures enèrgiques, moviments poderosos i expressió d'intensa emotivitat. En l'obra del Pedró, hom podria imaginar-se una imatge de la patrona representada com una donzella jove amb túnica ampul·losa i els atributs habituals del seu martiri, la palma i la creu en aspa (imatge 1). Els cabells recollits deixen veure un rostre delicat marcat per un patiment serè, que podria remetre a models berninians. ${ }^{17}$

16. El monument en fusta realitzat per Josep Darderi s'inaugurà el 1673 amb grans festes. Però es deteriorà aviat i el consell confià el 1683 als artistes Lluís Bonifaç i Llàtzer Tramullas una nova versió en marbre de la santa i de l'obelisc en jaspi que la sustentava, i el novembre de 1687 s'enllestí l'obra amb la inscripció dels noms dels promotors. Miquel Colomer col·laborà en el basament, el paleta Jaume Arnaudies i l'argenter Hilari Fornaguera feren la corona i la palma de coure de la santa.

17. Bonifaç, que provenia de França, s'establí a Barcelona amb el seu pare Francesc a finals dels anys setanta. A Barcelona realitzà també el Sant Pau del pati de la Casa de Convalescència (1678) i les imatges per al retaule de Santa Magdalena a la catedral (1688). Pel que fa als models, s'ha apuntat un ressò amb la Santa Bibiana de Bernini (1624-1626), que havia estat traslladada al gravat per Robert van Audenaerde. Miralpeix, 2006: 204-206. 
La del Pedró no fou l'única piràmide estable a Barcelona en els segles moderns ni tampoc la més antiga. A la plaça del Blat o de l'Àngel també s'hi havia erigit una piràmide el 1616 en substitució de la pedra que commemorava un miracle obrat per santa Eulàlia. El projecte s'encarregà a Rafael Plansó i consistia en una piràmide coronada per un àngel que amb la mà esquerra assenyalava la imatge de santa Eulàlia esculpida el 1456 sobre l'arc del portal d'entrada a la ciutat que donava accés a la baixada de la presó (avui baixada de la Llibreteria) i que, amb la mà dreta, assenyalava el lloc exacte del miracle. Sota el relleu de santa Eulàlia del portal hi havia una inscripció que recordava el fet miraculós de la santa en immobilitzar el seu cos fins que li fos retornat un dit que havia estat robat de la relíquia (Pi i Arimon, 1854: 367; Perelló, 1996: 338-348). Actualment es conserva encara l'escultura de l'àngel feta el 1618 per l'argenter Felip Ros, habitual col-laborador de l'Ajuntament de Barcelona i de la Generalitat. A més de la piràmide projectada pel Consell de Cent el 1689 en honor a sant Ramon de Penyafort que no s'arribà a fer, encara, el 1706, es feu construir al Born una piràmide dedicada aleshores a la Concepció, davant la porta posterior de Santa Maria del Mar. Fou encarregada per l'arxiduc Carles després de resistir el setge d'aquell any i testimonia l'expansió del culte a la Immaculada en aquella època (Mollfulleda, 2007: 111).$^{18}$ Així, doncs, l'Eulàlia del Pedró, malgrat que perdura amb la rèplica de Frederic Marès de 1951, és l'única peça d'estatuària pública encarregada pel govern de la ciutat que data del segle XVII, i en aquests monuments cal veure-hi «(...) la materialització de l'esperit de l'època barroca donada als efectes visuals» (Perelló, 1996: 338).

Les informacions registrades en les relacions de festes eixamplen el nostre coneixement del passat artístic des de diverses perspectives, com la dels usos i funcions de les obres. Al dietari del Consell s'informa que el sermó en honor a la santa es va dir «(...) estant tota l'església entapissada de draps de ras», i a la relació s'especifica que «los preciosisimos Tapices de la Diputación» estaven penjats al claustre (Manual, XX: 261; Festivos: 19). Sense cap altre esment ni descripció, roman el dubte sobre la identificació exacta de les peces. Al llarg del segle XVI hi ha documentades diverses compres de tapissos per part del Palau de la Generalitat. A més d'uns draps de ras amb la història de sant Jordi adquirits el 1547, es van comprar tres lots de tapissos flamencs (Garriga, 2012: 56-59). El primer constava de quatre peces de la sèrie dels Triomfs de Petrarca de la manufactura de Frans Geubels de Brussel-les i adquirides el 1571 al cavaller Jaume Terça de Tortosa. El segon comprenia vuit peces de la sèrie dels amors de Mercuri i Herse teixides a Brussel-les el 1574 per Willem de Pannemaker i adquirides pel capità general Fernando de Toledo el 1578 per a decorar la nova sala de la Diputació del General. El tercer lot corresponia a deu tapissos de la sèrie de les Històries de Noè (1565-1566) adquirits pel mateix Fernando de Toledo el 1583. Malgrat que de manera incompleta i dispersos en diferents institucions, encara avui se'n conserven un bon nombre. Si bé es fa difícil aventurar una hipòtesi sobre les peces

18. El text de Mollfulleda és l'estudi més complet sobre la piràmide barcelonina. També s'esmenta en estudis més amplis sobre monuments europeus del segle XVIII, com Chastel-Rousseau, 2011. 
que penjaven de les parets el 1686, semblaria que el tema religiós de Noè hauria estat més adequat per decorar l'ambient catedralici. Es tractava d'una rèplica de la mateixa manufactura que el taller de Pannemaker havia teixit en primera edició per encàrrec de Felip II entre 1561 i 1563 amb cartrons atribuïts a Michael Coxcie (1499-1592), prolífic pintor de Malines que havia treballat a Roma i que traslladà a Flandes el romanisme que pogué admirar de l'estil de Rafael (Garriga, 2012: 53 i 59; Garganté, 2015: 408). Dos dels tres tapissos que es conserven, avui decoren la capella de Sant Jordi del Palau de la Generalitat. Altres fragments conservats confirmarien la hipòtesi que degué existir una sèrie de composicions per il-lustrar gran part del Gènesi. Tanmateix, a banda de possibles conjectures, aquesta presència de tapissos testimonia l'ús habitual d'aquestes peces a l'època moderna per a decorar les esglésies i institucions públiques amb motiu d'actes litúrgics.

Amb més seguretat es pot identificar l'escultura que tancava la processó, el tabernacle principal portat pels sacerdots, el qual «(...) era un cuerpo bellissimo de plata dorado de la Santa que en años atrás mandò labrar la Ciudad, esmaltado en la Corona, Cruz y Palma, de finissimos diamantes, y bellissimas perlas. Llevavan el Palio los muy Ilustres Señores Confelleres» (Festivos: 19). La magnífica escultura de santa Eulàlia, feta d'argent daurat i obrada per Joan Perutxena, roman encara avui com un important testimoni religiós i artístic del segle XVII català i es conserva al museu de la catedral (imatge 2). Perutxena entrà al gremi barceloní el 1619 i el 1624 realitzà per encàrrec del canonge i ardiaca Pau Pla (1577-1625) una escultura de plata de la Immaculada que regalà a la catedral (Bosch, 2009: 246). En uns anys de promoció del culte immaculista, el 1638 confiaren a Perutxena una altra imatge de la Concepció per a l'altar major de Santa Maria del Mar «del meteix pès y valor, modo y forma que per la església de la Seu» (Bassegoda, 1925-1927: 108, nota 7). Fou durant els primers anys de la Guerra dels Segadors, el juliol de 1644, que el Consell de Cent deliberà encarregar a Perutxena una escultura d'argent de la patrona, una imatge votiva i processional que calia fer «[...] conforme la imatge de nostra $\mathrm{s}^{\mathrm{a}}$. de la Conceptio de la Seu que feu fer lo quondam sr. Ardiaca Pla» (Manual, 1913, vol. XIV: 13). El 1648 l'artista realitzà una altra imatge de santa Eulàlia per a Santa Maria del Mar, «de plata, de pès 500 onces, com la que dit argenter féu per la ciutat». Tenint en compte que d'aquests encàrrecs tan sols ha perviscut la Santa Eulàlia de la catedral, és interessant almenys assenyalar-ne la dependència amb la Immaculada de la Seu, que esdevingué un model tant per a imatges de l'advocació immaculista com de la patrona, ${ }^{19}$ i qui sap si inspirà altres escultures efímeres.

En un punt del relat, el cronista anònim sembla «falsejar» la història, ja que descriu la processó que es va fer el 1339 amb motiu del trasllat de les relíquies de

19. Francesc Via també havia de tenir en compte les obres de Perutxena a la catedral i a Santa Maria quan li encarregaren una Immaculada per a la Seu de Lleida el 1670, que no es conserva (Bosch i Roig, 1991: 318). El seu fill també orfebre, Francesc Via menor, es trobà la mateixa demanda en elaborar una Mare de Déu de la Cinta per al capítol tortosí el 1705-1706, que es conserva al tresor de la catedral de Tortosa (Vidal, 2004). 


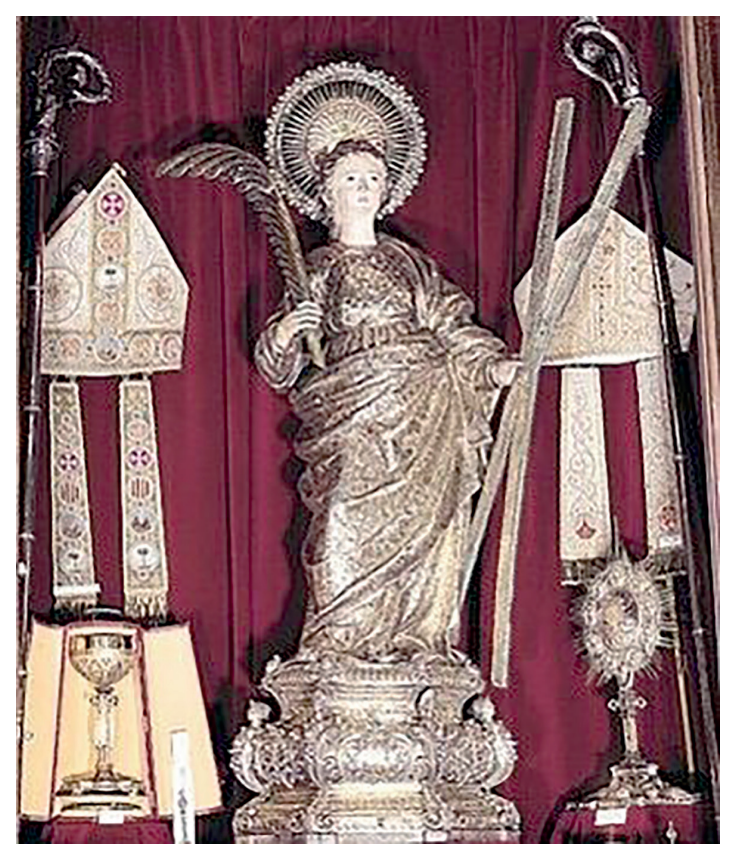

Imatge 2. Joan Perutxena, escultura d'argent de santa Eulàlia, 1644 (?), Museu de la Catedral, Barcelona.

la santa i es fa referència a la bandera de Santa Eulàlia que duia el canonge de la catedral d'aleshores, Guillem de Torrelles, «(...) en la qual avia una Cruz blanca en campo rojo, que es el escudo de la dicha Seo, y una Imagen de santa Eulalia, que en la mano izquierda tenia la dicha Cruz, y en la derecha un ramo de Palmas» (Festivos: 52). De ben segur que no es tracta de la bandera de Santa Eulàlia presidida per la imatge de la patrona conservada al Museu d'Història de Barcelona, atribuïda a Benet Sanxes Galindo (ca. 1582) i restaurada recentment (Garriga, 2001: 8; Bracons, 2013). En canvi, la descripció recorda més l'estendard de la confraria de Santa Eulàlia que es conserva encara al museu de la catedral i que dataria d'inicis del segle XVIII. Si bé només apareix referenciat als arxius catedralicis des de 1522, des de finals del segle XV aquest penó que encapçalava les processons de la catedral fou assimilat com a bandera de la ciutat amb l'afegit de l'escut (Triadó i Subirana, 2008: 54-55), i també s'ajusta a la descripció que en fa Jeroni Pujades al seu dietari en la processó per a la canonització de sant Ramon de Penyafort (Pujades i Casas, 1975).

Altres obres descrites eren relleus o escenes pintades, d'entre les quals crida l'atenció l'enginy que inventaren els de la confraria de Santa Eulàlia per a la seva piràmide en què «(...) el pie ò Vasa desta Piramide, era una bellíssima perspectiva 
formada de 36 columnas doradas, por entre las cuales con proporcionado movimiento iva dando la buelta una rueda, con que por su orden successivo se ivan viendo todos los passos del Martyrio de la Santa muy bien imitados, fue muy aplaudida la idea de este Altar»(Festivos: 110). A més de la part mecànica de l'enginy, resulta interessant la representació dels martiris de la patrona, tal com també es mostrava al tabernacle dels trinitaris descalços i al dels servites (Festivos: 118, 119).$^{20}$ Per a representar escenes martirials de la patrona, els artistes moderns podrien haver seguit els models de les obres medievals presents a la catedral, com el sarcòfag obrat per Lupo di Francesco al segle XIV (Bracons, 1993) o el rerecor de la seu amb els relleus de Bartolomé Ordóñez primer i de Pedro Villar i Claudi Perret posteriorment, que s'havien dut endavant sota el patronatge del bisbe Sanç (Bosch, 2000-2001; Garriga i Carbonell, 1986: 117; Duran i Sanpere, 1972, vol. I: 360). O tal vegada s'inspiraren en alguna obra avui perduda, com fou la versió del martiri en una pintura de Pere Cuquet, contractada pel Consell de Cent el 1648 (Perelló, 1996: 234). ${ }^{21}$

Mirar d'establir els models de les obres efímeres perdudes també condueix a interrogar-se sobre la presència de pintures semblants que s'han conservat fins als nostres dies. Es tracta de dues teles anònimes, en què la imatge de la jove nua martiritzada a l'eculi domina la composició i el relleu de la ciutat es dibuixa al darrere. ${ }^{22}$ Aquestes obres permeten imaginar com devien ser altres obres efímeres semblants, en què la nuesa de la santa destacaria en uns anys d'estrictes observances en la pintura (imatge 3). ${ }^{23}$ Tot i que escenes similars havien aparegut en gravats de Jean Desvargues (imatge 4), de Lió (1664) que es versionaren en el taller dels Abadal amb mínimes diferències (1679) (Socias, 2007: 119-120), la santa no es mostrava nua i, en general, la majoria de les imatges modernes catalanes de santa Eulàlia no en representaren el martiri. En les pintures conservades, els artistes semblen haver-se concentrat precisament en el patiment de la santa, amb una monumentalització de la figura vista des de baix i la mirada alçada que condueix al món celestial, en què uns àngels la reben amb un filacteri i una palma de màrtir. El dramatisme de l'instant, que s'accentua a través de la llum, s'adiu amb la petició que es feia als cartells anunciadors del concurs de poesies i pintures en què es demanava precisament la interpretació del martiri per part dels poetes i en què es veu referida la possible inspiració en els relleus de la catedral

20. En el tabernacle dels trinitaris descalços, sota la imatge de la Verge dels Remeis hi apareix «(...) la Santa, padeciendo el martyrio de las Achas encendidas», i en el dels servites es recordava «(...) la Santa venia a Barcelona y encontrava con el Tirano, que estava sentado en una silla muy rica, era la postura de la Santa, de una Donzellita tierna, muy airosa y denodada».

21. A més de santa Eulàlia, també havia de pintar el martiri de sant Andreu, els bisbes sant Pacià, sant Oleguer, sant Sever i sant Policarp, santa Madrona i sant Ramon de Penyafort i Nostra Senyora de la Concepció.

22. Agraeixo al Dr. Francesc Miralpeix haver-me-les donat a conèixer. Una es conserva a la Reial Acadèmia Catalana de Belles Arts de Sant Jordi i l'altre oli, provinent del desaparegut convent de Sant Francesc de Barcelona, a 1'Arxiu Històric de l'Hospital de la Santa Creu i Sant Pau. La filiació d'aquesta segona amb el relleu de Pedro Villar la feu Santiago Alcolea (Garriga i Martín González, 1996: 382; Fontbona, 1999: 97, núm. 976).

23. Sobre la qüestió de la nuesa i la censura, vegeu Gacto, 2006. 


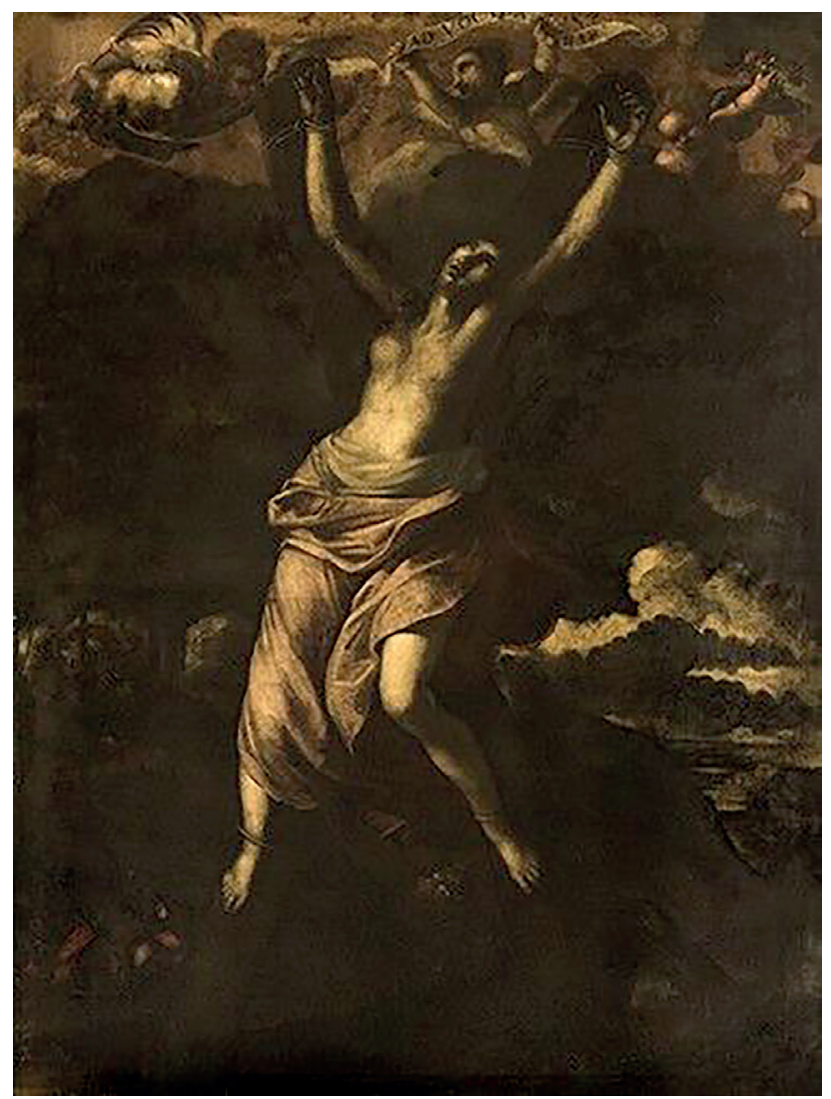

Imatge 3. Escola de Josep Juncosa (?), Santa Eulàlia a l'eculi, oli sobre tela, segle XviI, Reial Acadèmia de Belles Arts de Sant Jordi.

(Festivos: 16). ${ }^{24}$ Val la pena recordar aquí les indicacions de Gabriele Paleotti sobre la representació dels sants i llurs martiris, en què el cardenal demanava als artistes que mostressin l'horror dels turments que havien patit. A la cripta de la catedral de San Pietro a Bolonya, al programa iconogràfic projectat per Paleotti,

24. «Padeció Eulalia glorioso Martyrio con aquella forma de Cruz que comúnmente llaman las Aspas de S. Andres, la qual en este Principado ha mudado el nombre, y se llama la Cruz de Santa Eulalia, siendo mas razón, que por lo que estuvo amartelada por ella, viva y muerta, se 1lamase Santa Eulalia de la Cruz: digna cuestión esta para decidida en el Senado de las Musas, y así al que con mayor acierto resolviere qual fue mayor fineza en Eulalia, estar en los braços de la Cruz, viva, ù quedar al pie della, muerta, como lo vemos en el Templo Maximo de Barcelona, y lo terminare en pulido elegante verso latino, de qualquier metro, se le darà en premio una Salva de brunyada plata». 


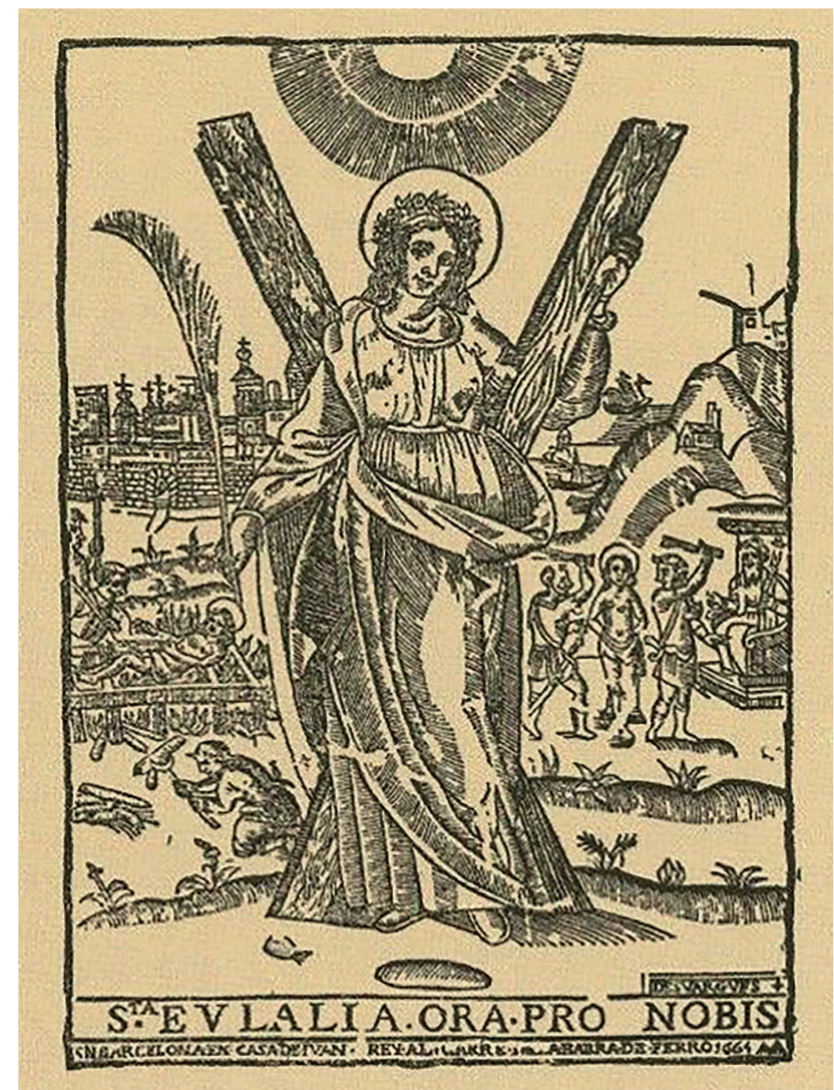

Imatge 4. Jean Desvargues, Santa Eulàlia ora pro nobis, 1664.

els sants havien de ser representats «in strane guise tormentari» $\mathrm{i}$ es privilegiaven les llàgrimes de les figures i els recursos semblants perquè, tal com defensava Lomazzo, «(...) a despertar la contemplació és necessària la malenconia» i així, «(...) els sants miren el cel, tenen les mans alçades com l'orant de les catacumbes» (Bianchi, 2008: 114, 144 i 140). Aquestes idees també influïren en la creació de les imatges de sants franceses i hispàniques i aquesta actitud impassible amb la mirada clavada al cel és característica del màrtir, que reprèn models de l'heroi pagà i influències del misticisme grec, amb llurs idees sobre allò mortal i allò transcendent (Rodríguez G. de Ceballos, 2002; Martínez-Burgos, 2013; Frank i Malgouyres, 2015).

A més de la representació del martiri de santa Eulàlia, és també remarcable l'aparició del relleu de la ciutat de Barcelona en dues de les obres descrites, el 


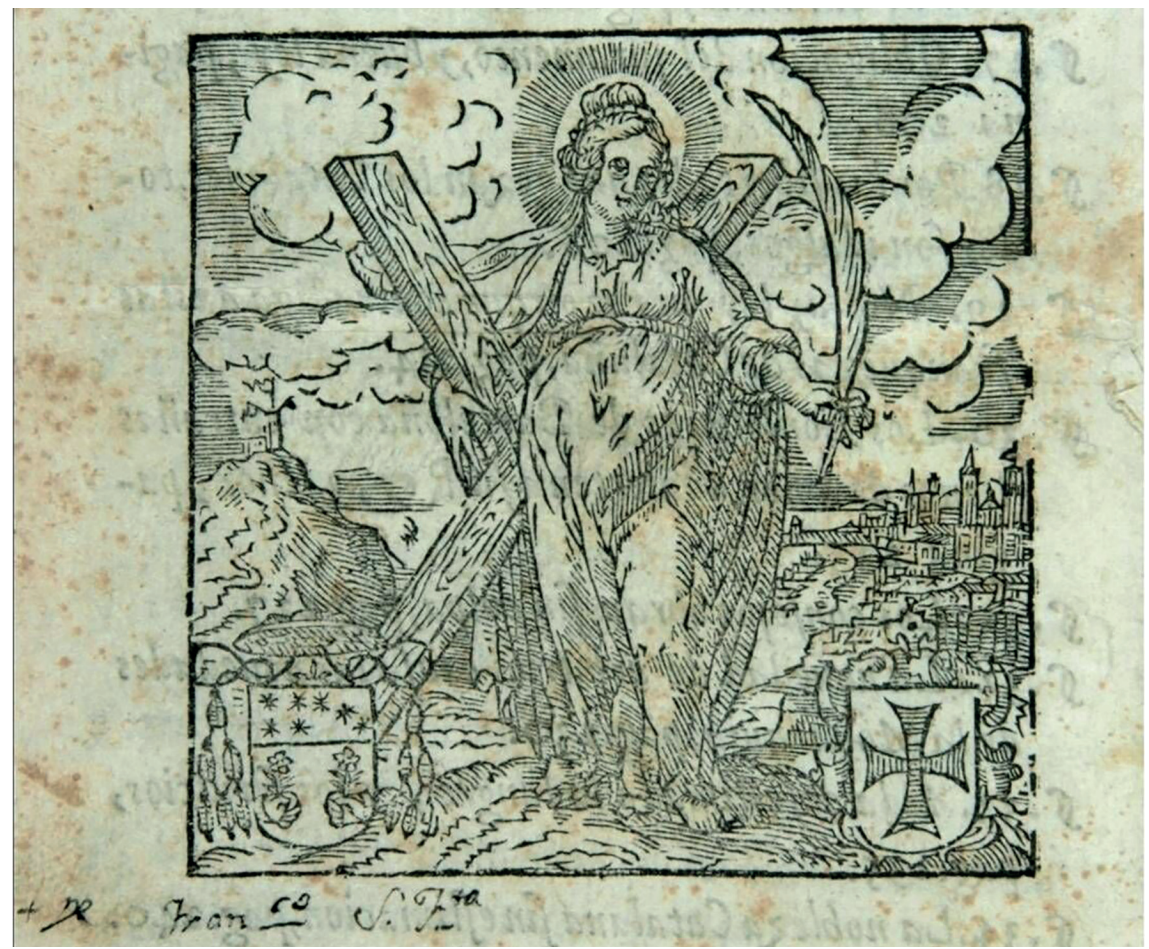

Imatge 5. Gravat anònim de Santa Eulàlia a l'obra de Lluís Sans i Manegat Ordinarium seu Rituale Ecclesiae Barchinonensis..., editat per Sebastià Comellas, Barcelona, 1620. Biblioteca de Catalunya.

tabernacle dels servites i el dels carmelites. En el dels servites, que també era una imatge martirial de la santa nua amb els ulls clavats al cel sobre un promontori, a sota «(...) se formava la Ciudad de Barcelona con sus Plaças, Calles, Templos, Torres, y Murallas, todo de carton, que parecia ella misma, no se dejaron los Baluartes, y puertas ni su Artillería, la qual por secretos conductos que avia en la traça disparava toda junta; en lo mas alto estava la atalaya de Monjuy, que con todos sus aparatos de pomos, y vanderas, y la Montaña sombrada de ganados, y poblada de Arboles, en fin fue un remedo de todo lo que ay en esta Ciudad» (Festivos: 118 i 119). ${ }^{25}$

25. En el cas dels carmelites, el seu tabernacle fou aplaudit, i es tractava també: «(...) de un remedo de toda esta Ciudad con Calles Plaças, y Edificios, plantada a la Orilla de un Mar con su Puerto, y en él diversidad de embarcacions, estaba à la ladera el Promontorio de Monjuy que con diversidad de casevias; muchos arboles, y ganados, en medio de la Ciudad ideado un Palacio, y por la parte que mira à Sarrià, Lugárcillo segun se dice de la Santa venia a Barcelona». 
Aquesta identificació de la santa amb la ciutat a través del relleu de Barcelona al rerefons ja havia aparegut en algunes obres, sobretot gravats, que en temps de la Guerra dels Segadors s'havien repetit com a il-lustració d'alguns dels textos més combatius d'aleshores. Es refermava així el lligam identitari de la patrona amb els partidaris del Consell de Cent i es testimoniava l'habitual reaprofitament de les planxes i les imatges en la gràfica catalana (Fontcuberta, 2016; Miralles, 2012). Així, a la coberta de llibres de Francesc Martí i Viladamor o de Gaspar Sala, hi apareixia una imatge anònima de santa Eulàlia flanquejada per dos escuts i davant d'un paisatge clarament barceloní, que provenia del llibre Ordinarium seu rituale ecclesiae Barcinonensis de 1620 del bisbe Lluís Sanç i Manegat, que havia estat el responsable de l'acabament de les obres del rerecor de la catedral (imatge 5). ${ }^{26}$ Pel que fa a la vista de Barcelona, el fet que el perfil de la ciutat sembli capgirat, amb la muntanya de Montjuïc a l'esquerra i la ciutat a la dreta però amb el mar enmig, fa pensar en la possibilitat que el gravador es fixés en un model o planxa anterior o el reutilitzés també aquí. En una altra obra d'aquell moment, una pintura votiva que al-ludia a la batalla de 1641 i que es conserva al castell de Montjuïc, es mostrava la Verge amb santa Eulàlia i santa Madrona i la muntanya de Montjuïc al darrere (Miralpeix, 2012: 255).

Aquestes peces porten a recordar que les festes, els actes i les obres catalanes descrites aquí s'inscriuen en un llarg període de construcció de sants locals o identitaris a recer de les tesis contrareformistes en molts territoris d'Europa. Tant catòlics com protestants havien impulsat una historiografia documental que justifiqués les seves arrels antigues (Cavallotto, 2009; Scavizzi, 1982). Si Maties Flaci vinculava la Reforma amb els primers cristians, l'historiador Cesare Baronio i l'arqueòleg Antonio Bossi van indagar en arxius i catacumbes i van publicar obres monumentals per establir l'autenticitat de les relíquies dels primers màrtirs i legitimar la primacia de l'Església romana (Martyrologium Romanum, 1583). Justament, a la relació de 1686 se cita Cesare Baronio per tal de documentar la cronologia de santa Eulàlia (Festivos: 121). ${ }^{27}$

Tal com va advertir fa dècades Emile Mâle, les representacions dels martiris es van revestir d'un aspecte de veritat històrica completament nou i els artistes van haver de rebre a vegades indicacions concretes (Mâle, 2001: 130). En l'important debat sobre la licitud i els usos de les imatges en temps de les Reformes, el cardenal Paleotti coneixia perfectament aquelles fonts que proporcionaven les imatges de sants i màrtirs com a exempla virtutis per als fidels, com les pintures de Pomerancio Circignani a l'església de Santo Stefano Rotondo a Roma (1583), iconografia segurament creada pel pare Gallonio, amic de Baronio i Bossi. Les pintures tenien una clara finalitat didàctica, partien de composicions molt clares $i$ es basaven en notícies històriques, i aviat es conegueren a través de gravats (Bianchi, 2008: 106). A més d'aquests gravats i l'obra de Cesare Baronio, Paleotti també coneixia i es basà, entre d'altres, en el Martirologio de Molano (1568) o el Vitae Sanctorum de Surio (1570). El cardenal Paleotti recomanava en el seu

26. Biblioteca de Catalunya, 2-III-5.

27. Sobre la influència de Baronio en l'art, De Maio, 1985. 
Discurs sobre les imatges (1582) que, en la representació dels sants, els artistes s'adherissin al grau de versemblança més alt possible i el màxim als fets històrics, que quan fos possible es partís de la vera efígie del retratat i que es respectés una ambientació correcta, amb un amor per la topografia, «(...) una col-locació que connota i col-loca també geogràficament el sant, alliberant-lo de costums iconogràfics desiguals i ahistòrics que no parlen fort i clar» (Bianchi, 2008: 140). Paleotti exhortava els pintors a ocupar-se de la dada natural i, per tant, a pintar pobles i territoris veritables. Aquest interès del cardenal pel paisatge es fa palès en algunes obres d'artistes com Bartolomeo Cesi (1556-1629) que treballaren aquells anys en el programa pictòric de la cripta de la catedral de San Pietro a Bolonya i que hi traduïren visualment les recomanacions del cardenal en escenes com la de sant Bruno, en què l'artista pintà darrere el sant l'arquitectura de la Certosa di Bologna (Bianchi, 2008: 138; Pigozzi, 2015). A més, és també interessant apuntar la tesi segons la qual en l'època de Gregori XIII s'assisteix a un canvi dels modes de representació de l'espai a través de la producció difusa de cartes geogràfiques, mapes i mapamundis (Emiliani, 1994), i caldria tenir present la influència de la cartografia en la configuració d'aquests paisatges rere els sants.

Diverses comunitats religioses però també civils, com ciutats i regions, cercaren cossos sants per a mostrar i exhibir la seva catolicitat o justificar-ne la canonització, i aparegueren cicles hagiogràfics il-lustrats, es redactaren martirologis i s'editaren i il-lustraren les vides de sants. Es reclamaven tant els sants medievals com el seu paisatge, tant temporal com geogràfic, i, entre d'altres, Richard Verstergan situava les escenes dels martiris en paisatges anglesos al Descriptiones quaedam illius inhumance et multiplicis persecutionis (1583-1584), per tal de donar forma a la identitat catòlica després de la persecució de catòlics a Anglaterra entre 1535 i 1603 (Dillon, 2002).

Cal recordar que les indicacions del cardenal Paleotti van ser divulgades al món hispànic per teòrics com Francisco Pacheco, qui en l'Arte de la pintura (1641) aconsellava als artistes que consultessin als experts i erudits per a l'adequació i decor en la iconografia religiosa (Pacheco, 2009). Igualment, els tractats i escrits d'autors com Gallonio i Baronio sobre els martiris dels sants es conegueren a Espanya (De la Peña, 2012). Al món hispànic també influïren altres vides de sants, com el Flos Sanctorum del jesuïta Pedro de Ribadeneyra, que posava l'accent en l'eloquiència dels turments dels sants per al camí cristià (VincentCassy, 2011: 56). Justament, a Barcelona s'editaren nombrosos exemplars, sempre en castellà, tant de Ribadeneyra com d'Alonso de Villegas (Valsalobre, 2012: 116). A Madrid, al convent d'agustines recol-lectes de La Encarnación s'hi pintà una versió del cicle de martiris de Circignani amb alguns canvis i una altra versió del segle XVII es troba en part al convent de San Pablo de Valladolid (VincentCassy, 2008; Vincent-Cassy, 2011: 85-89; Urrea, 2007). També arribà a terres peninsulars la sèrie de vint-i-quatre gravats de santes i màrtirs de Thomas de Leu (1560-1612) de cap a finals del segle XVI, que probablement feu per encàrrec del col-legi jesuïta d'Anvers. El Martyrologium Sanctarum Virginum fou reeditat uns anys més tard pel també gravador flamenc Adriaen Collaert en una sèrie que 


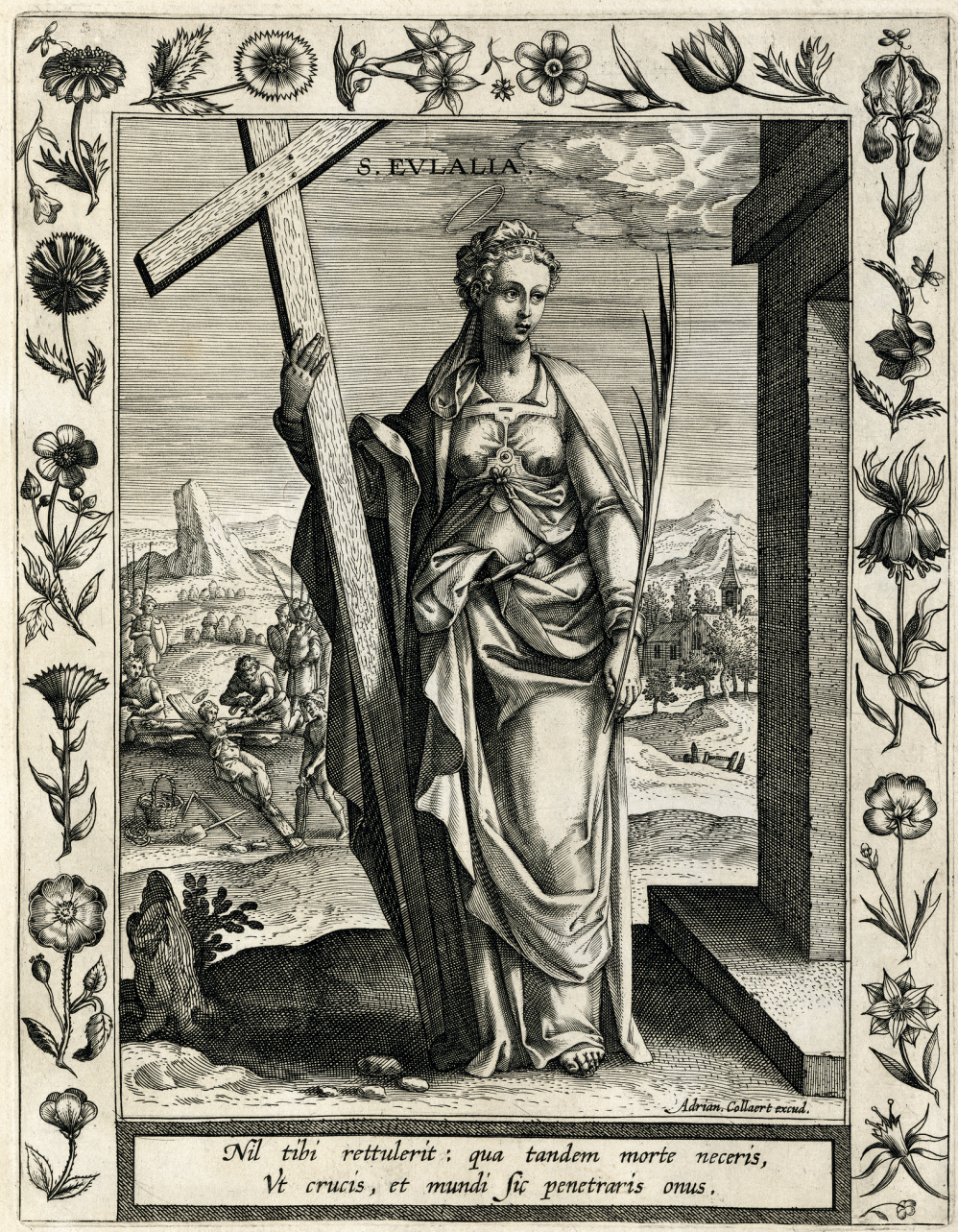

Imatge 6. Adriaen Collaert, Santa Eulàlia, de Martyrologium Sanctarum Virginum, $19.5 \times$ $15 \mathrm{~cm}$, finals del segle XVI.

dedicà a Margarida, filla de Maximilià II i religiosa de Las Descalzas de Madrid (Vincent-Cassy, 2011: 70-76). En aquestes estampes, Leu situava les santes en primer pla amb llurs atributs a les mans i prenien postures meditatives amb els ulls perduts en la vaguetat, mentre les acompanyava un paisatge al darrere amb escenes narratives, freqüentment dels seus martiris. Entre aquestes santes del segle III s'hi va incloure santa Eulàlia, en una imatge que recorda la composició del gravat anònim del bisbe Sanç (imatge 6). 
Tornant a Barcelona, el Consell de Cent havia patrocinat tots els actes previs per a la promoció de l'extensió del res de santa Eulàlia. Així, tal com consta en el dietari i també es registra a les Rúbriques de Bruniquer, el Consell de Cent el 10 de novembre de 1685 entregà a l'escrivà i notari Jacint Borràs «(...) la llàmina gran de aram de la gloriosa verge y màrtir Sancta Eulàlia y duas de petitas y síon posades dins una capsa de fusta y tancat dins lo armari de la plata» (Manual, XX: 229; Bruniquer, 1912-1916: 182). Probablement es tracta del gravat que el mateix Consell encarregà al francès Barthélemy Chasse per tal d'acompanyar la súplica de la ciutat al rei Carles II demanant la seva mediació davant el sant pare perquè aquest concedís l'extensió universal del res de la santa el 1685 (imatge 7). Com és sabut, entre tota la documentació que s'enviava a Roma en els processos de beatificació i canonització dels sants, a més dels textos hagiogràfics també hi havia estampes, que ajudaven a representar les heroïcitats dels candidats. Chasse va ser a Barcelona el 1686, on feu alguna altra estampa, i després s'instal-là a Marsella (Cornudella, 1999: 160) ${ }^{28}$ En aquesta obra de qualitat artística superior als estàndards de la calcografia autòctona, la santa es representa enmig d'un evocador paisatge de runes antigues, entre les quals hi ha fragments de columnes clàssiques i amorets que sostenen uns escuts amb les imatges del martiri. Al darrere es dibuixa el perfil d'una ciutat, potser Roma, però no es correspon amb el relleu barceloní. En canvi, el gravat de Lesoing realitzat en dates properes (ca. 1680) ja incorpora el relleu urbà amb una vista des de la muntanya cap al mar (Muñoz, 1997: 155). ${ }^{29}$ De manera semblant al cas del martiri, també han perviscut algunes pintures dels segles XVII i XVIII que s'inscriuen en aquest marc devocional i artístic i que conformen un ventall de propostes plàstiques que testimonien la combinació freqüent de la representació de la santa i la ciutat. Un exemple (imatge 8) es conserva a la sagristia de la catedral de Barcelona fent pendant amb una santa Madrona i que per la seva qualitat i estil s'ha atribuït al cercle de Francesc Tramulles (1722-1773) (Triadó i Subirana, 2008: 98-99). Se'n conserva una altra a Vilafranca del Penedès de més tardana, datada el 1789.30 Entre d'altres pintures de santa Eulàlia que es troben al mercat artístic, una obra anònima de grans dimensions mostrava justament una vista àmplia de la ciutat, ara protegida per una patrona de dimensions menors. ${ }^{31}$

El paisatge jugà un paper important a l'hora de forjar les identitats confessionals i de reconfigurar la memòria social, tal com s'ha posat en relleu en el cas de l'art britànic, i aquestes imatges mostraven la provinença dels sants i en refermaven el lligam (Walsham, 2011: 211). En relació amb l'apropiació religiosa de la geografia en les demandes tridentines, i tornant a la devoció i l'art barcelonins, Eulàlia no fou l'única protagonista de l'skyline contrareformista. La canonització

28. L'obra es conserva a la Biblioteca de la Universitat de Barcelona.

29. Un exemplar es conserva al Museu Nacional d'Art de Catalunya: MNAC.GDG.3741 G.

30. Es tracta d'una pintura a l'oli anònima, de dimensions 120 x 76 x $12 \mathrm{~cm}$. Número de registre 5842, Museu de les Cultures del Vi (Vinseum).

31. L'escut de Barcelona a l'esquerra i la santa a la dreta completen la pintura, que va ser subhastada el 2013 al Château de Saint Antoine (Gers, Midi-Pyrénées). Vegeu la referència a Canalda, 2015: 40. També hi havia disponible la reproducció de la pintura. 


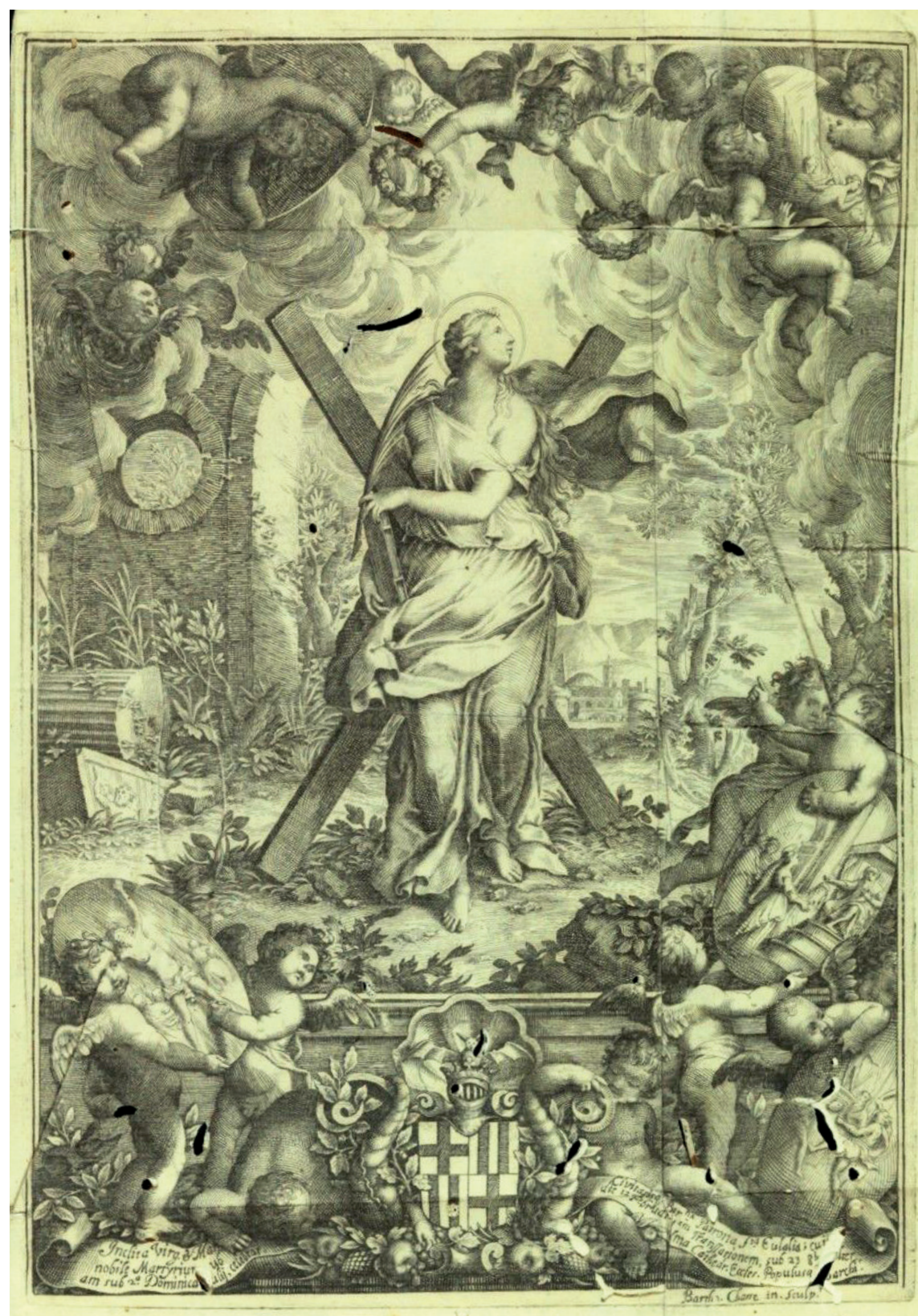

Imatge 7. Barthélemy Chasse, Santa Eulàlia, gravat calcogràfic, ca. 1685. Universitat de Barcelona. 


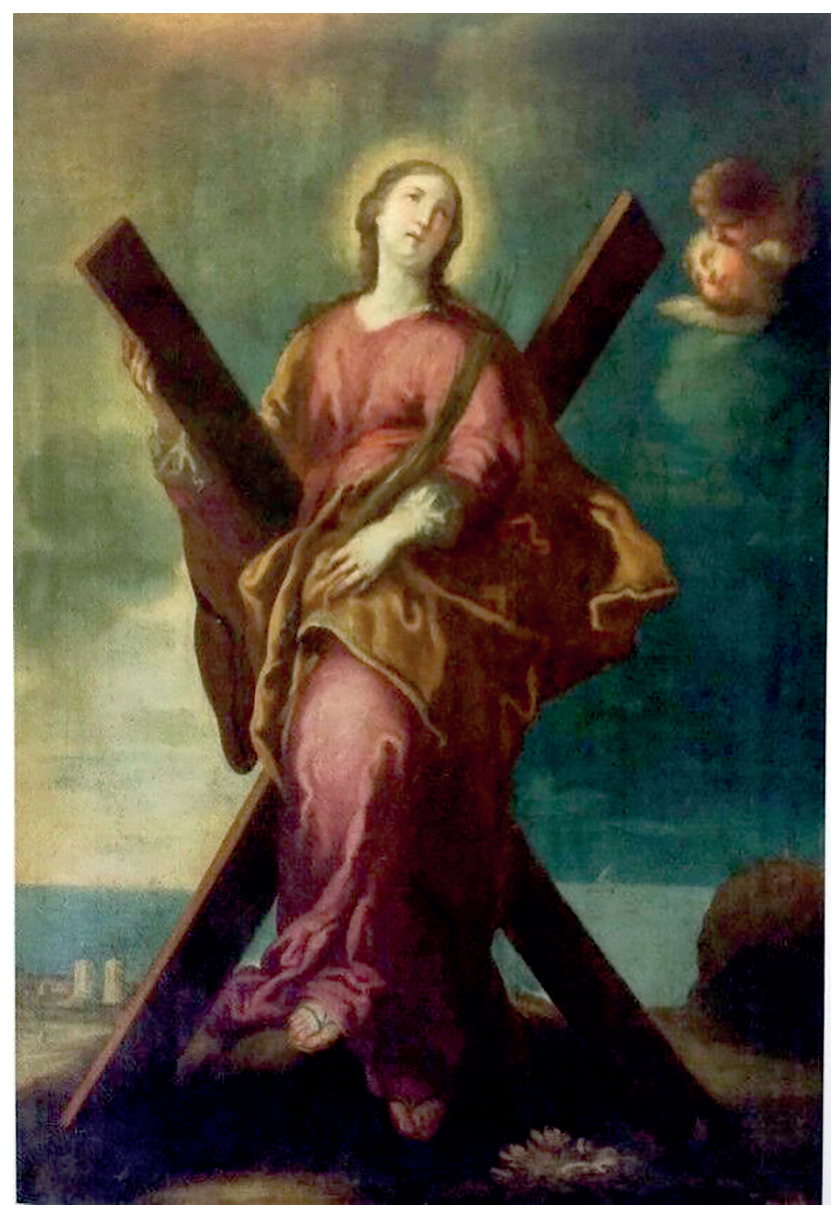

Imatge 8. Anònim (cercle de Francesc Tramulles), Santa Eulàlia, oli sobre tela, $114 \times 76$ $\mathrm{cm}$, segle XVIII, sagristia de la catedral de Barcelona.

de sant Ramon de Penyafort el 1601 impulsà nombroses imatges i es creà una iconografia moderna del primer sant català de la Contrareforma. Justament, en una de les estampes editades l'any de la canonització, el perfil de Montjuïc i de Barcelona apareixen al darrere de l'escena de la Transfretació del sant, un dels seus miracles més coneguts (Dilla, 2017: 444). ${ }^{32}$ Altres obres mostraren el relleu

32. L'obra està signada pel gravador d'origen francès, però actiu a Roma des de finals del segle XVI, Christophe Blanc. Es reprodueix un exemplar conservat a Vilafranca del Penedès, probablement elaborat després d'haver manipulat i reimprès l'original entre 1725-1747. 


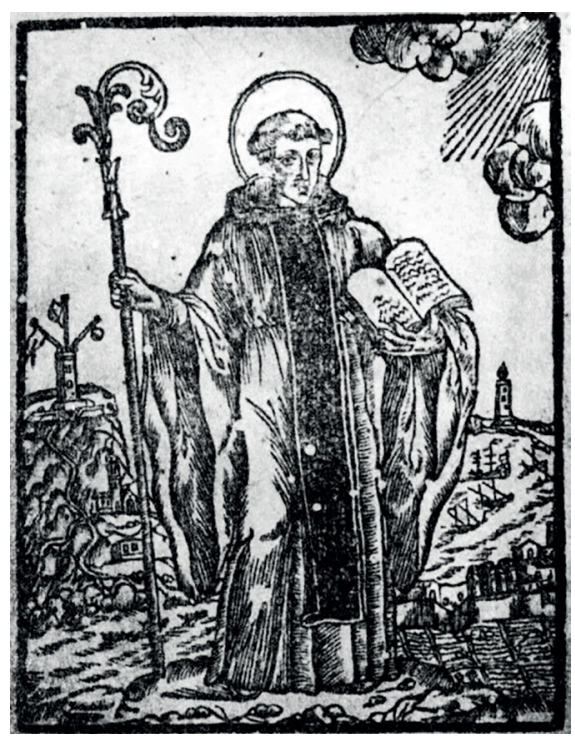

Imatge 9. Gravat anònim, Sant Ramon de Penyafort, inicis del segle XVII, Barcelona, AHCB.G.1455.

barceloní darrere el sant al llarg dels anys, com les estampes de Sadeler (1601), que situa el miracle del sant en un paisatge marítim, o la sèrie de Jean Le Clerc (1622) en què sembla situar l'escena en una vila que podria ser Sóller (Dilla, 2017: 446 i 451). Si bé altres pintures amb la vista de Barcelona al darrere eren obres romanes, com la de santa Sabina o la de santa Maria di Montserrato, malauradament no es coneix cap exemplar d'una estampa que alguns artistes catalans devien tenir ben present cap a 1686 quan es va donar fe de la imatge elaborada a Roma per la canonització del sant. Aquesta obra costejada per la Ciutat, la Corona i el Principat, presentava diverses escenes en una composició semblant a la d'altres cicles hagiogràfics. ${ }^{33}$ En canvi, una xilografia anònima mostra el sant català amb les Decretals a una mà i el bàcul a l'altra, dempeus davant el paisatge barceloní que s'identifica per la muntanya de Montjuïc amb la torre de senyalització marítima i el santuari de Santa Madrona a un costat, i les muralles i els horts de la ciutat amb la llanterna del port a l'altre (imatge 9). La particularitat de la vista és que el perfil està capgirat, la qual cosa faria pensar en una rellevància més icònica que descriptiva de l'estampa, i en un possible antecedent visual i model per al gravat del bisbe Sanç (imatge 5). ${ }^{34}$

33. El prior del convent de Santa Caterina de Barcelona havia fet reunir en aquesta ciutat el 1684 a un grup de frares i artistes, entre els quals Andreu Sala, Joan Arnau, Mateu Janer i Felip Ros, per donar fe de l'estampa davant notari (Dilla, 2017: 436-443).

34. Per a una reproducció del gravat vegeu Muñoz, 1997: 151. 
De fet, en la relació de 1686 també s'esmenten altres sants de gran devoció a la ciutat, com sant Jordi, que juntament amb santa Eulàlia decorava el frontispici guanyador del concurs, d'en Maurici Rotxoli del carrer Ample (Festivos: 113, 104). En l'altar construït pels mercedaris es representaven la Verge de la Mercè i santa Eulàlia. Justament, al cap d'uns mesos, el 1687, la Verge de la Mercè fou assignada també patrona de Barcelona després de ser invocada pel Consell de Cent davant la plaga de llagosta que assolava la població. Malgrat que el patronatge fos ratificat pel papa molt tardanament, el 1868, a partir d'aleshores el perfil barceloní aparegué també en imatges dedicades a l'advocació mercedària, com el gravat de Francesc Gazan amb la Verge i el Nen acompanyats d'àngels sobre la ciutat (Triadó, 1984: 123) o com la gran pintura votiva de 1690 en què els sis consellers es van fer retratar encomanant-se a l'estol de sants barcelonins comandats aquí per la Verge de la Mercè, i entre els quals apareix santa Eulàlia, amb la vista de Barcelona al fons (Miralpeix, 2012: 248) ${ }^{35}$ De fet, la silueta barcelonina havia estat utilitzada com a rerefons de la pintura en què el conseller Bonaventura Gualbes s'havia fet retratar als peus de santa Madrona, en una peça de patronatge particular atribuïda a Abdó Ricart i datada el 1661 (Triadó, 1984: 116-117; Farías, 2017), o de sants avui menys populars però igualment pertanyents al santoral cívic de la ciutat com santa Maria de Cervelló, sant Josep Oriol, santa Àngela Margarida Serafina, sant Adjutori, Nostra Senyora dels Desemparats o santa Agnès i santa Clara. La ciutat de Barcelona en època moderna, doncs, es definia i es representava amb el santoral cívic i el perfil urbà. ${ }^{36}$

Gràcies a les relacions escrites tenim constància d'obres desaparegudes i esdevenen fonts que ens permeten alhora contextualitzar les obres que han perviscut fins avui. L'itinerari ofert aquí n'esdevé una proposta, un possible recorregut que permet ampliacions i revisions. Sens dubte, però, totes aquestes obres esmentades formaven part del «gran teatre» del món barroc en què les arts confluïen en un espectacle total, que podem almenys imaginar a través de relacions de festes com aquesta.

\section{Bibliografia}

Ainaud de Lasarte, J. (1989). «L'arquitectura efímera a la Barcelona del segle XVII». A: El barroc català. Barcelona: Quaderns Crema, 411-421.

Bassegoda Amigó, B. (1925-1927). Santa María de la Mar: monografía histórica-artística, 2 vols. Barcelona: Fills de J. Thomas.

Betrán Moya, J. L. (2010). «Culto y devoción en la Cataluña barroca». A: E. Serrano (coord.). Fábrica de santos: España, siglos XVI-XVII. Jerónimo Zurita, 85, 95-132.

Bianchi, I. (2008). La politica delle immagine nell'età della Contrariforma. Gabriele Paleotti storico e commitenti. Bolonya: Editrice Compositore.

35. Aquesta obra anònima que celebrava la fi de la plaga de llagosta que assolava la ciutat es conserva al MNAC.

36. Vegeu la contribució de Laura Farías i Cristina Fontcuberta «Entre el mar, la ciutat i el cel: la presència de la costa mediterrània en les imatges dels sants patrons de Barcelona (segles XVIXVIII)» en el marc del VIII Congrés d'Història Moderna de Catalunya el desembre de 2018. 
Boiteux, M. (1985). «L'Espagne et les fêtes romaines au Xvire siècle». A: M. FAGiolo, M. L. Madonna. Barocco romano e barocco italiano. Roma: Gangemi editore, 117-134.

Bonet Correa, A. (1990). Fiesta, poder y arquitectura. Aproximaciones al barroco español. Madrid: Akal.

Bosch, J. (2000-2001). «Pedro Vilar, Claudi Perret, Gaspar Bruel i el rerecor de la catedral de Barcelona». Locus Amoenus, 5, 149-177.

- (2009). Agustí Pujol. La culminació de l'escultura renaixentista a Catalunya. Barcelona: Publicacions de la Universitat de Barcelona, Col·l. Memoria Artium, 7.

Bosch, J., Roig, A. (1991). Paisatge després de la tempesta: la memòria de l'art del segle XvII a la Seu Vella. Lleida: Congrés de la Seu Vella.

Bracons, J. (1993). «Lupo di Francesco, mestre pisà, autor del sepulcre de Santa Eulàlia». D'Art, 19, 43-52.

- (2013). La bandera de santa Eulàlia i la seva restauració. Barcelona: Ajuntament de Barcelona, MUHBA, Llibrets de Sala, 14.

BruniQuer, E. G. (1912-1916). Ceremonial dels magnífichs consellers y regiment de la Ciutat de Barcelona, vol. 3. Barcelona: Impr. d'Henrich.

Burkhardt, J. (2004 (1860)). La cultura del Renaciminento en Italia. Madrid: Akal.

CAmpos, F. J. (2002). «La fiesta barroca, fiesta de los sentidos». A: G. Fernández, F. Martínez (coords.). La fiesta del Corpus Christi. Conca: Ediciones de la Universidad de Castilla-La Mancha, 91-121.

Canalda, S. (2015). «El retrat del port de Barcelona pel pintor Mariano Sánchez, 1788». Barcelona Quaderns d'Història, 22, 33-48.

Cavallottto, S. (2009). Santi nella Riforma. Da Erasmo a Lutero. Roma: Viella.

Cea Gutiérrez, A. (1992). Religiosidad Popular: Imágenes Vestideras, Zamora: Caja España, Obra Cultural.

Chastel-Rousseau, C. (2011). Reading the Royal Monument in eighteenth-century Europe. Londres: Ashgate.

Cornudella, R. (1999). «Els orígens de Miquel Sorelló i la calcografia a Barcelona, c. 1600-1725». Estudis Històrics i Documents dels Arxius de Protocols, 17, 153-211.

De la PeÑa, C. (2012). «La imagen del mártir en el barroco: el ánimo invencible». Archivo Español de Arte, LXXXV, 338, 147-164.

De MaIo, R. et al. (1985). Baronio e l'arte: atti del convegno internazionale di studi. Sora: Centro di Studi Sorani Vincenzo Patriarca.

Díez, R. (1986). Il trionfo della parola nella Roma barocca (1623-1667). Roma: Bulzoni.

Dilla, R. (2017). Sant Ramon de Penyafort: imatge, devoció i santedat. Tesi doctoral inèdita. Universitat de Barcelona.

Dillon, A. (2002). Construction of Martyrdom in the English Catholic Community, 15351603. Aldershot: Ashgate.

Dompnier, B. (2009). Les cérémonies extraordinaires du catholicisme baroque. Presses Universitaires Blaise Pascal.

D’Onofrio, C. (1967). Gli obelischi di Roma. Roma: Bulzoni.

Duran i SAnpere, A. (1972). Barcelona y la seva història, vol. I. Barcelona: Curial.

Emiliani, A. (1994). «Gli anni di Gregorio XIII Buoncompagni: il tempo e lo spazio». A: V. Fortunati (cur.). Lavinia Fontana 1552-1614. Milà: Electa, 53-73.

Estella, M. (1993). «Obras maestras inéditas del arte de la cera en España». Goya, 237, 149-160.

Ettinghausen, H. (2001). «De la noticia a la prensa (San Raimundo de Peñafort, Barcelona, 1601)». A: C. STrosetzKi (ed.). Actas del V Congreso Internacional de la Asociación Internacional Siglo de Oro. Madrid: Iberoamericana-Vervuet, 490-502. 
Ettinghausen, H. (2010). «Barcelona, centre mediàtic del segle XVII, i les seves relacions de festes». A: García Espuche, A. Festes i celebracions: Barcelona 1700. Barcelona: Ajuntament de Barcelona, 199-275.

Fagiolo, M. (1997). La Festa barocca. Roma: De Luca.

Fagiolo, M., CARANDini, S. (1977-1978). L'Effimero barocco: strutture della festa nella Roma del '600, 2 vols. Roma: Bulzoni.

FARÍAS MuÑoz, L. (2017). «Del text a l'estampa: representacions de santa Madrona en literatura d'època moderna». Matèria: revista d'art, 12, 71-90.

Feliu de la Penya, N. (1999). Anales de Cataluña y epílogo breve de los progressos y famosos hechos de la nacion catalana. Barcelona: 1709, edició facsímil Barcelona: Base.

Fernández Terricabras, I. (2011). «La implantació de la Reforma catòlica a les terres de parla catalana (1563-1700). Un procés reeixit?». Catalan Historical Review, 4, 227 240.

(1686 o post) Festivos y magestuosos cultos que la nobilissima y muy illustre ciudad de Barcelona en 23 y 30 de octubre 1686 dedicò a su inclita hija, patrona, virgen y protomartyr Santa Eulalia: motivados en la extension del rezo proprio de la santa que obtuvo para toda España de Innocencio XI con decreto despachado en Roma en 31 de agosto 1686. En Barcelona: en casa Cormellas, por Iayme Cays.

Fontbona, F. (1999). Catàleg del Museu de la Reial Acadèmia Catalana de Belles Arts de Sant Jordi. Barcelona: Reial Acadèmia Catalana de Belles Arts de Sant Jordi.

Fontcuberta i Famadas, C. (2016). «"La capitana en campanya": la imatge de Santa Eulàlia en època moderna. Usos polítics i transformacions iconogràfiques d'un culte medieval». A: R. Alcoy (ed.). L'Art Medieval en Joc (EMAC-contextos; 4). Barcelona: Publicacions de la Universitat de Barcelona, 213-229.

- (2018). «El culte i la imatge de santa Eulàlia en la Barcelona moderna (segles XVIXVIII)». A: O. PAscual (ed.). Santa Eulàlia, patrona de Barcelona. Barcelona: Ajuntament de Barcelona, 93-117.

Frank, L., Malgouyres, P. (2015). La fabrique des saintes images. Rome-Paris, 15801660. París: Louvre.

GACTO, E. (2006). «El Arte vigilado (Sobre la censura estética de la Inquisición en el siglo XVIII)». A: C. PEÑA (coord.). En torno al Barroco. Miradas múltiples. Múrcia: Editum, 155-209.

García Bernal, J. J. (2006). El Fasto Público en la España de los Austrias. Sevilla: Publicaciones de la Universidad de Sevilla.

- (2013). «Perpetuo Milagro: la memoria prestigiosa y perdurable de la fiesta religiosa barroca (1590-1630)». Chronica Nova. Revista de Historia Moderna de la Universidad de Granada, 39, 75-114.

García Espuche, A. (2010). Festes i celebracions: Barcelona 1700. Barcelona: Ajuntament de Barcelona.

Garganté, M. (2011). Festa, arquitectura i devoció a la Catalunya del Barroc. Barcelona, Publicacions de l'Abadia de Montserrat.

-(2015). «La Sala nova del consistori. Un espai per a la representació del poder». A: M. Carbonell. El Palau de la Generalitat. Barcelona: Generalitat de Catalunya, 380-408.

Garriga, J. (2001). «Benet Sanxes Galindo, pintor i poeta del segle XVI a Catalunya». Estudi General, 21, 69-129.

-(2012). «La col-lecció de tapisseries flamenques de la Seu Vella de Lleida». A: X. ComPANY, I. Puig. L'art de la tapisseria a l'Europa del Renaixement. Lleida: Polièdrica, $16-21$. 
Garriga, J., Carbonell, M. (1986). Història de l'art català: s. xVI. Vol. IV. L'època del Renaixement. Barcelona: Edicions 62.

Garriga, J., Martín González, J. J. (coords.) (1996). Fons del Museu Frederic Marès 13. Catàleg d'escultura i pintura dels segles XVI, XVII $i$ XVIII. Barcelona: Ajuntament de Barcelona.

Henares Paque, V. (2006). «Iconografía de la imagen exenta del niño Jesús». Catálogo de la exposición de imágenes del Niño Jesús. Marchena.

JACQUOT, J. (1960). Les fêtes de la Renaissance: Fêtes et cérémonies au temps de Charles Quint. París: Editions du CNRS.

MÂLe, E. (1985). El Barroco: arte religioso del siglo XVII. Italia, Francia, España, Flandes. Madrid: Encuentro.

-(2001 (1932)). El arte religioso de la Contrareforma. Madrid: Encuentro.

(1892-1975). Manual de novells ardits vulgarment apellat Dietari del Antich Consell Barceloní. Barcelona: Imprempta de'n Henrich y Companyia, vol. XX.

Maravall, J. A. (1990). La Cultura del Barroco: análisis de una estructura histórica. Barcelona: Ariel.

Martinell, C. (1948). «El escultor Luis Bonifás y Massó: 1730-1786: biografía crítica». Anales y Boletín de los Museos de Arte de Barcelona, vol. VI, 1-2.

Martínez-Burgos, P. (2013). «Imágenes emocionadas. Devoción e identidad en la España moderna». A: S. CAnAlda, C. Fontcuberta (eds.). Imatge, devoció i identitat a l'època moderna. Barcelona: Edicions de la Universitat de Barcelona, 13-31.

(1583). Martyrologium Romanum: ad nouam kalendarij rationem, \& ecclesiasticae historiae veritatem restitutum. Ex typographia Dominici Basae.

Mata, S., PARís, J. (2006). Els Bonifaç, una nissaga d'escultors. Valls: Institut d'Estudis Vallencs.

Mercader, S. (2015). Els monuments de Setmana Santa de la Catedral de Barcelona. Barcelona: Publicacions de l'Abadia de Montserrat.

Mínguez, V., González, P. (2011). La fiesta barroca en el reino de Valencia (15991802). València: Universitat Jaume I.

Miralles, E. (2012). «Els escriptors catalans en una Europa en conflicte: la propaganda política impresa de la Guerra dels Segadors». Caplletra, 52, 181-205.

Miralpeix, F. (2006). A: J. Bosch. Alba daurada: l'art del retaule a Catalunya, 16001792 circa. Barcelona: Generalitat de Catalunya.

- (2012). «Pestes, plagas y guerras. El encargo artístico votivo en la Cataluña de la segunda mitad del siglo XVII». A: X. Torres (ed.). Les altres guerres de religió. Catalunya, Espanya, Europa (segles XVI-XIX). Girona: Documenta Universitària, 231-256.

- (2017). Processó de Diumenge de Rams de la Venerable i Il-lustre Arxiconfraria de la Verge dels Dolors del convent del Bonsuccés de Barcelona, fitxa MHCB 7616.

Mollfulleda, C. (2007). «In futuri operis signum. La piràmide de la Inmaculada i el setge de Barcelona de 1706». A: M. Morales, M. Renom, M. Cisneros (coords.). Actes del Congrés l'Aposta Catalana a la Guerra de Successió (1705-1707). Barcelona: Generalitat de Catalunya, 109-124.

MuÑoz, J. M. (1997). «Iconografía urbana de Cataluña (siglos XVI-XVIII). Una aproximación tipológica y teórica». D’Art, 23, 135-161.

Norberg-Schulz, C. (1980). Arquitectura barroca. Madrid: Aguilar.

(1620) Ordinarium, seu Rituale Ecclesiae Barchinonensis/Ludouici Sans episcopi..., Barcelona: ex typographia Sebastiani à Cormellas.

Pacheco, F. (2009). El Arte de la pintura. Barcelona: Cátedra, ed. de Bonaventura Bassegoda. 
Pedraza, P. (1982). Barroco efímero en Valencia. València: Ayuntamiento de Valencia.

Perelló, A. M. (1996). L’Arquitectura civil del segle XVII a Barcelona. Barcelona: Publicacions de l'Abadia de Montserrat.

Pi I Arimon, A. A. (1854). Barcelona antigua y moderna, o descripción y historia de esa ciudad desde su fundación hasta nuestros días. 3 vols. Barcelona: imprenta Tomás Gasch.

Pigozzzi, M. (2015). «Il decoro e la storia. Gli esiti del Concilio di Trento». A: M. PIgozZI (ed.). Il Concilio di Trento e le arti 1563-2013. Bolonya: Bononia University Press, 7-51.

Pujades, J., Casas, J. M. (1975). «Dietari de Jeroni Pujades I (1601-1605)». Memorias de la Real Academia de Buenas Letras de Barcelona, vol. 15, 67-172.

Redondo, A. (2002). «Les relaciones de sucesos de la fin du Xvie siècle et du début du XVIIe, face au message tridentin. Quelques aspects du culte des saints». A: Les arts et les lettres de la Contre-Réforme en Espagne, ed. de L. Anselem-Szende, Cauces, 3, 135-150.

Río Barredo, M. J. (2000). Madrid Urbs Regia. La capital ceremonial de la Monarquía Católica. Madrid: Marcial Pons.

Rivera de las Heras, J. A. (1992). Imágenes del Niño Jesús. Zamora: Caja España Obra Cultural.

RodríGuez de LA Flor, F. (1999). «Economía simbólica de la relación de conmemoración fúnebre en el Antiguo Régimen: gasto, derroche y dilapidación del bien cultural». A: S. López (coord.). La fiesta: actas del II Seminario de Relaciones de Suceso. A Coruña, 121-132.

Rodríguez G. De Ceballos, A. (2002). «El mártir, héroe cristiano: los nuevos mártires y la representación del martirio en Roma y en España en los siglos XVI y XVII». Quintana, 1, 84-99.

Rossich, A. (2003). «Els certàmens literaris a Barcelona, segles XIV-XVIII». Barcelona Quaderns d'Història, 9, 83-108.

SÁnChez López, J. A. (2010). «Juventud invicta, infancia triunfante: hagiografía, mito y presencia y culto en las catedrales españolas del Barroco». A: G. RAMALlo AsENSiO (coord.). La catedral guía mental y espiritual de la Europa Barroca Católica. Universidad de Murcia, 103-208.

Sans i Travé, J. M. (2014). Dietaris de la Generalitat de Catalunya 1411-1713, vol. VIII. Anys 1674 a 1689. Barcelona: Generalitat de Catalunya.

ScavizzI, G. (1982). Arte e architettura sacra: cronache e documenti sulla controversia tra riformati e cattolici 1500-1550. Reggio Calabria: Casa del Libro.

SigüEnZA, R. (2015). «Escultura en cera, el barroco y Santa Teresa de Jesús». A: F. J. CAMpos (coord.). Santa Teresa y el mundo teresiano del Barroco. Instituto Escurialense de Investigaciones Históricas y Artísticas. Simposium, 695-710.

Socias, I. (1993). «El contracte dels quatre gravats dels novíssims, entre l'impressor i gravador Joan Jolis Santjaume i Magí Cases, doctor en teologia». Pedralbes, 13 (2), 449462.

-(2007). Els Abadal, un llinatge de gravadors. Barcelona: Publicacions de l'Abadia de Montserrat.

Strong, R. (1988 (1984)). Arte y poder. Fiestas del Renacimiento 1450-1650. Madrid: Alianza.

Torres, X. (2014). «La ciutat dels sants: Barcelona i historiografia de la Contrareforma». Barcelona Quaderns d'Història, 20, 77-104.

Torres, X., Exposito, R. (2015). «Relaciones de sucesos y religión cívica en la Barcelona moderna». A: J. GARcía, S. BoAdAs (eds.). Las relaciones de sucesos en los cambios 
políticos y sociales de la Europa Moderna. Universitat Autònoma de Barcelona, 413425.

TozzI, S. (2002). Incisioni baroche di feste e avvenimenti: giorni d'allegrezza. Roma: Gangemi.

Triadó, J. R. (1984). L’Època del barroc s. XVII-XVIII. Barcelona: Edicions 62, col·l. Història de l'Art Català, vol. 5.

—(1999). «La festa i les manifestacions efímeres a la Catalunya del segle XVIII. Proposta d'Estudi i d'anàlisi». A: Miscel-lània en homenatge a Joan Ainaud de Lasarte. Barcelona: Publicacions de l'Abadia de Montserrat, II, 135-142.

- (2016). «Escultura catalana del barroco». A: A. Fernández Paradas (coord.). La escultura barroca española: nuevas lecturas desde los siglos de oro a la sociedad del conocimiento, vol. 3. Málaga: Exlibric, 399-483.

Triadó, J. R., Subirana, R. M. (2008). Memòria del Barroc. Tresors de la Catedral de Barcelona i del Museu Diocesà de Barcelona. Barcelona: Museu Diocesà de Barcelona.

Urrea, J. (2007). «Martirio de los Santos Águeda, Abdón, Senén, Fabián, Cipriano y Trifón. Martirio de los Santos Policarpo, Justino y Victor». A: Museo Nacional de Escultura V: Pintura entre lo real y lo devoto. Valladolid, 24-27.

VAlsalobre, P. (2012). «Elements per a una Catalunya sacra: sobre alguns aspectes de l'hagiografia de l'edat moderna catalana». A: M. Garcia, M. À. LlorCA (eds.). Vides medievals de sants: difusió, tradició i llegenda. Alacant: Institut Interuniversitari de Filologia Valenciana, 99-122.

Vidal, J. (2004). Les imatges de la Mare de Déu de la Cinta. Barcelona: Generalitat de Catalunya.

(1686). Villancicos que se cantaron en la segunda fiesta que la muy illustre ciudad de Barcelona hizo en su Santa Cathedral Iglesia, á su invicta Patrona... Santa Eulalia el 30 de octubre deste año 1686 por el Licenciado Iuan Barter, en Barcelona: en casa Cormellas, por Iayme Cays.

Vincent-Cassy, C. (2008). «Un ciclo romano en la Encarnación de Madrid». A: M. Cruz, P. Civil, F. Pereda, C. Vincent-Cassy. La imagen religiosa en la Monarquía hispánica. Usos y espacios. Madrid: Casa de Velázquez: 39-59.

-(2010). «Los santos, la poesía y la patria. Fiestas de beatificación y canonización en España en el primer tercio del siglo XVII». A: E. SERrano (coord.). Fábrica de santos: España, siglos XVI-XVII. Jerónimo Zurita, 85, 75-94.

-(2011). Les saintes vierges et martyres dans l'Espagne du XvIIe siècle: culte e imatge. Madrid: Casa de Velázquez.

Walsham, A. (2011). The Reformation of the Landscape. Religion, Identity, and Memory in Early Modern Britain and Ireland. Oxford: Oxford University Press.

WitTKower, R. (1979). Arte y arquitectura en Italia, 1600-1750. Madrid: Cátedra. 